\title{
Geochemical records of palaeoenvironmental controls on peat forming processes in the Mfabeni peatland, Kwazulu Natal, South Africa since the Late Pleistocene
}

A. Baker, Joyanto Routh, M. Blaauw and A.N. Roychoudhury

\section{Linköping University Post Print}

\section{Tweet}

N.B.: When citing this work, cite the original article.

Original Publication:

A. Baker, Joyanto Routh, M. Blaauw and A.N. Roychoudhury, Geochemical records of palaeoenvironmental controls on peat forming processes in the Mfabeni peatland, Kwazulu Natal, South Africa since the Late Pleistocene, 2014, Palaeogeography, Palaeoclimatology, Palaeoecology, (395), , 95-106.

http://dx.doi.org/10.1016/j.palaeo.2013.12.019

Copyright: Elsevier

http://www.elsevier.com/

Postprint available at: Linköping University Electronic Press

http://urn.kb.se/resolve?urn=urn:nbn:se:liu:diva-106296

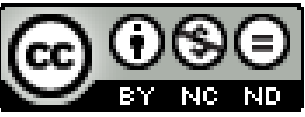





\title{
Geochemical records of palaeoenvironmental controls on peat forming processes in the Mfabeni peatland, Kwazulu Natal, South Africa since the Late Pleistocene
}

\author{
A. Baker ${ }^{a}$, J. Routh ${ }^{b^{*}}$, M. Blaauwc, A.N. Roychoudhury ${ }^{\mathrm{a}}$

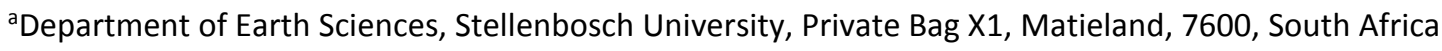

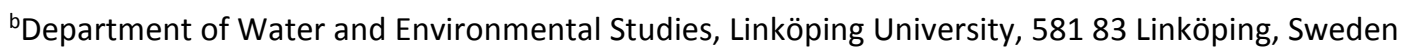 \\ 'School of Geography, Archaeology and Palaeoecology, Queen's University Belfast, Belfast BT7 1NN, U.K.
}

\section{Abstract}

The Mfabeni peatland is the only known sub-tropical coastal fen that transcends the Last Glacial Maximum (LGM). This ca. $10 \mathrm{~m}$ thick peat sequence provides a continuous sedimentation record spanning from the late Pleistocene to present (basal age c. $47 \mathrm{kcal}$ yr BP). We investigated the paleaeoenvironmental controls on peat formation and organic matter source input at the Mfabeni fen by: 1 ) exploring geochemical records (mass accumulation rate, total organic carbon, carbon accumulation rate, $\delta^{13} \mathrm{C}, \delta^{15} \mathrm{~N}$ and $\mathrm{C} / \mathrm{N}$ ratio) to delineate primary production, organic matter source input, preservation and diagenetic processes, and 2) employ these geochemical signatures to reconstruct the palaeoenvironmental conditions and prevailing climate that drove carbon accumulation in the peatland. We established that the Mfabeni peat sediments have undergone minimal diagenetic alteration. The peat sequence was divided into 5 linear sedimentation rate (LSR) stages indicating distinct changes in climate and hydrological conditions: LSR stage 1 (c. 47 to c. $32.2 \mathrm{kcal}$ yr BP): predominantly cool and wet climate with C4 plant assemblages, interrupted by two short warming events. LSR stage 2 (c. 32.2 to c. $27.6 \mathrm{kcal}$ yr BP): dry and 
windy climate followed by a brief warm and wet period with increased C4 sedge swamp vegetation. LSR stage 3 (c. 27.6 to c. $20.3 \mathrm{kcal} \mathrm{yr} \mathrm{BP}$ ): initial cool and wet period with prevailing C4 sedge plant assemblage until c. $23 \mathrm{kcal}$ yr BP; then an abrupt change to dry and cool glacial conditions and steady increases in C3 grasses. LSR stage 4 (c. 20.3 to c. 10.4 kcal yr BP): continuation of cool and dry conditions and strong C3 grassland signature until c. $15 \mathrm{kcal}$ yr BP, after which precipitation increases. LSR stage 5 (c. $10.4 \mathrm{kcal}$ yr BP to present): characterized by extreme fluctuations between pervasive wet and warm to cool interglacial conditions with intermittent abrupt millennial-scale cooling/drying events and oscillations between C3 and C4 plant assemblages. In this study we reconstructed a highresolution record of local hydrology, bulk plant assemblage and inferred climate since the Late Pleistocene, which suggest an anti-phase link between Southern African and the Northern Hemisphere, most notably during Heinrich (5 to 2 ) and Younger Dryas events.

Key words: Palaeoenvironment; subtropical peatland; stable isotopes; elemental analyses; carbon accumulation.

\section{1. Introduction}

2 Peatlands play a pivotal role in the global carbon (C) cycle, serving as a direct link between

3 the short-term (atmosphere, biosphere and hydrosphere) and long-term (geosphere)

4 carbon reservoirs. Under sequestering conditions, peatlands serve as sinks for atmospheric

$5 \mathrm{CO}_{2}$, important sources of $\mathrm{CH}_{4}$ and exporters of fluvial dissolved and particulate organic

6 carbon to down-stream ecosystems (Worrall et al., 2003). The balance between ecosystem

7 productivity and respiration, controlled primarily by precipitation, temperature, water table

8 fluctuation and local topography, determines if a peatland acts as a C sink or source. 
9 Contemporary global peatland C stocks have been estimated to be in excess of 450

Petagrams $\left(1 \mathrm{Pg}=10^{15} \mathrm{~g}\right)$, equivalent to $75 \%$ of $\mathrm{CO}_{2}$ stored in the atmosphere at any given

time (Strack, 2008). The vast majority ( 90\%) of peatlands are found in the Northern

Hemisphere temperate and boreal regions, with tropical and sub-tropical peatlands constituting the balance (Immirzi et al., 1992; Page et al., 2011). However, because of their relatively higher carbon accumulation rate (CAR; Chimner and Ewel, 2005; Strack, 2008), tropical peatlands are estimated to represent up to a quarter of the potential global peatland C stock (Strack, 2008; Page et al., 2011), and they are at a greater risk of

degradation and overexploitation due to their proximity to populated areas and climate change (Rieley et al., 1996). Currently, there is limited scientific understanding of the processes that regulate $\mathrm{C}$ cycling and accumulation in tropical peatlands (Chimner and Ewel, 2005), and how changing climate and increasing anthropogenic pressures will affect low latitude peatland systems and their ability to sequester $\mathrm{C}$.

Southern Africa is situated at the interface of tropical and temperate climate systems. The region is influenced by the largest asymmetrical cross-continental tropical convection (Stokes et al., 1997) as a consequence of seasonal fluctuations in the Inter Tropical Convergence Zone (ITCZ), and large temperature gradients between the warm Agulhas and cold Benguela oceanic currents (Preston-Whyte and Tyson, 1998; Tyson and Preston-Whyte, 2000). Due to the topography and semi-arid climate of Southern Africa, archives are not commonly preserved, and few continuous palaeoenvironment records exist (Chase and Meadows, 2007), despite strong evidence of climate variability from Antarctic ice cores and low latitude African hydrological investigations (Bard et al., 1997; Blunier et al., 1998; Gasse, 2000; Stocker, 2000; Stenni et al., 2001). A few detailed limnology studies have been 
undertaken in regional lakes (Meadows et al., 1996; Meadows and Baxter, 1999; Partridge, 2002; Kristen et al., 2010), but due to the fact that most of southern Africa is water scarce, freshwater lakes are uncommon. Speleothem archives from South African caves have yielded high-resolution climate records (Talma and Vogel, 1992; Lee-Thorp et al., 2001 Holmgren et al., 2003; Holzkämper et al., 2009), but these records either do not span the Last Glacial Maximum (LGM) or are incomplete with at least one or more hiatuses of between 2.5 and 10 kyr. Several palynology studies have been undertaken in regional coastal peatlands and hyrax midden deposits (Finch and Hill, 2008; Neumann et al., 2008, 2010; Walther et al., 2011; Valsecchi et al., 2013) however, with the exception of the Mfabeni peatland study (Finch and Hill, 2008) the palynology records are limited to the deglacial and Holocene periods. To our knowledge, the only geochemical palaeoclimatic study undertaken on the sub-tropical Braamhoek peatland in the austral summer rainfall region of South Africa is by Norström et al. (2009). This inland wetland is located on the Eastern escarpment at $1700 \mathrm{~m}$ a.s.I. and lies over $290 \mathrm{~km}$ from the nearest coastline with a palaeorecord extending only as far back as c. $16 \mathrm{kcal} \mathrm{yr} \mathrm{BP.}$

The lack of high-resolution terrestrial palaeoclimate records on the African sub-continent continues to hinder the understanding of past climate forcing factors and their environmental impacts (Chase and Meadows, 2007; Gasse et al., 2008). Additional high resolution multi-proxy and multi-archive studies are therefore needed to elucidate past climate fluctuations and modelling of the ensuing environmental responses to these changes in the future. In this context, organic matter (OM) rich peat deposits are ideally suited for palaeoenvironmental studies as they are well preserved archives that are subject to mainly autochthonous depositional regimes that are largely regulated by climate (Strack, 
2008). The aim of this research is to investigate climatic and environmental conditions that have prevailed in the southern African region since the Late Pleistocene. Our objective is to reconstruct the palaeoenvironmental controls on past $\mathrm{C}$ accumulation and $\mathrm{OM}$ source input at the sub-tropical coastal Mfabeni fen by: 1) delineating primary production, OM source input, OM preservation and diagenetic processes which affected the formation of these peat deposits, and 2) using multiple geochemical proxy signatures such as, mass accumulation rate (MAR), total organic carbon (TOC), carbon accumulation rate (CAR), $\delta^{13} \mathrm{C}$, $\delta^{15} \mathrm{~N}$ and $\mathrm{C} / \mathrm{N}$, to reconstruct the palaeoenvironmental conditions and prevailing climate in the peatland over the last c. $47 \mathrm{kcal} \mathrm{yr} \mathrm{BP.}$

\section{Methods}

\subsection{Site description}

St Lucia is one of the largest estuarine systems on the African continent (Vrdoljak and Hart, 2007). It falls within the UNESCO World Heritage iSimangaliso Wetland Park, situated on the northern shores of Kwazulu-Natal province, South Africa (Fig. 1). Lake St Lucia, the dominant north-south aligned water body, has an extent of $350 \mathrm{~km}^{2}$ and an average depth of only $90 \mathrm{~cm}$. At its northern end, the lake is fed by four regional rivers with a combined catchment of approximately $6085 \mathrm{~km}^{2}$, namely the uMkhuze, Nyalazi, Mzinene and Hluhluwe rivers. To the south, a narrow $22 \mathrm{~km}$ long waterway sporadically links the lake to the Indian Ocean, and to the east the lake is fed with fresh water by the large Maputuland unconfined aquifer (Kelbe et al., 1995; Taylor et al., 2006a).

The Mfabeni fen lies within an interdunal valley (Botha and Porat, 2007) on the eastern shores of Lake St Lucia, running parallel to the coastline and measuring ca. $10 \times 3 \mathrm{~km}$ 
78 (Clulow et al., 2012; Grundling et al., 2013), and thickness of up to ca. $11 \mathrm{~m}$ (Grundling, 2001; Grundling et al., 2013). The hydrological regime of the fen is controlled by local precipitation and circum-neutral $\mathrm{Ca}^{2+}$ and $\mathrm{HCO}_{3}{ }^{-}$dominated groundwater emanating from the Maputaland aquifer (Venter, 2003; Taylor et al., 2006b; Grundling et al., 2013). The region lies within a humid, sub-tropical climate which experiences primarily austral summer rainfall of between 900 and 1200 mm/yr (Grundling, 2001; Taylor et al., 2006a). However, modern rainfall data indicate distinctive wet and dry cyclical events which can effectively halve the annual precipitation for extended periods (Bate and Taylor, 2008). The surface waters on the eastern part of the minerotrophic Mfabeni peatland drain northwards into the southern part of Lake Bhangasi, while the western sections drain southwards into Lake St Lucia (Grundling, 2001; Clulow et al., 2012).

The Mfabeni fen forms part of the greater Natal Mire Complex (NMC; Fig. 1) that extends from southern Mozambique to the south of Richards Bay, Kwazulu-Natal (Smuts, 1992). The NMC falls within the Maputaland group of coastal Cenozoic deposits, constrained in the west by the Lebomobo monocline, uPongola and uMkhuze River valleys (Botha and Porat, 2007). The Mfabeni peatland accumulated by valley infilling on a lacustrine or intertidal non-permeable clay layer (Grundling et al., 2013) within the reworked late Pleistocene KwaMbonanbi Formation coastal dune depression (Smuts, 1992), as a consequence of blockage of the Nkazana palaeo-channel and sustained groundwater input from the Maputaland aquifer (Grundling et al., 2013).

The iSimangaleso wetland park encompasses several heterogeneous habitats, mainly as a response to topography, hydrology and historical land use (Vrdoljak and Hart, 2007). Mucina et al. (2006) broadly categorised the wetland habitats as Maputaland wooded 
grassland, coastal belt and sub-tropical freshwater wetlands surrounded by northern coastal forests. The Mfabeni fen vegetation is largely represented by herbaceous reed sedge vegetation (Finch, 2005), and is dominated by Rhynchospora holoschoenoide, Fimbristylis bivalve, Panicum glandulopaniculatum and Ischaemum fasciculatum (Lubke et al., 1992; Vaeret and Sokolic, 2008).

\subsection{Sampling techniques}

A $810 \mathrm{~cm}$ deep sediment core, SL6, was extracted from the middle of the peatland $\left(28.15021^{\circ} \mathrm{S} ; 32.52508^{\circ} \mathrm{E}\right)$ using a $5 \mathrm{~cm}$ diameter $\times 50 \mathrm{~cm}$ length Russian peat corer in June 2011. The core was logged in the field and described and sectioned into $1-2 \mathrm{~cm}$ increments in the laboratory. All samples were weighed before freeze-drying, then again afterwards to calculate bulk density and porosity of each segment.

\subsection{Radiocarbon dating / age model}

Evenly spaced samples were sent for ${ }^{14} \mathrm{C}$ dating at the Poznań Radiocarbon Laboratory, Poland. The sediments were chemically pre-treated as described by Brock et al. (2010) with the exception of using $0.25 \mathrm{M}$ instead of $1 \mathrm{M} \mathrm{HCl}$; samples SL1 31-32 and SL4 89-90 were not treated with $\mathrm{NaOH}$ due to their low carbon content. The samples were combusted with $\mathrm{CuO}$ and $\mathrm{Ag}$ wool at $900^{\circ} \mathrm{C}$ for $10 \mathrm{hrs}$ and the $\mathrm{CO}_{2}$ was reduced to pure graphite in a vacuum line as described by Czernik and Goslar (2001). Coal or IAEA C1 Carrara Marble and international modern Oxalic Acid II standards were subjected to the same pre-treatment and combustion procedure. The ${ }^{14} \mathrm{C}$ content of the samples were measured on a Compact Carbon AMS (National Electrostatics Corporation, USA) as described by Goslar et al. (2004). The conventional ${ }^{14} \mathrm{C}$ age was calculated using a correction factor for isotopic fractionation as per Stuiver and Polach (1977). 
Since the ages of some of the ${ }^{14} \mathrm{C}$ dates lie beyond the limit of the southern hemisphere calibration curve (McCormac et al., 2004), dates were calibrated using the Northern hemisphere terrestrial calibration curve IntCal09 (Reimer et al., 2006) while applying a southern hemisphere offset of $40 \pm 20{ }^{14} \mathrm{C}$ years. Post-bomb ages were calibrated using the southern hemisphere post-bomb curve of Hua and Barbetti (2004). All ages were adjusted within the Bayesian framework, using age-depth modelling software Bacon (Blaauw and Christen, 2011). This method divides a core into sections and models the accumulation rate for each of these sections. Accumulation rates were constrained by prior information (here a gamma distribution with mean $50 \mathrm{yr} / \mathrm{cm}$ and shape 1.5), and the variability of accumulation rate from one depth to the next was constrained by a 'memory' parameter (here using the default beta distribution with mean 0.7 and strength 4). Stable runs were obtained using multiple Markov Chain Monte Carlo (MCMC) iterations.

\subsection{Elemental and stable isotope analyses}

Selection of acid treated and raw samples were analysed for $\mathrm{C}$ and $\mathrm{N}$ stable isotopes composition and elemental ratios at the Department of Archaeology, University of Cape

Town. Peat samples were combusted in a Thermo Scientific Flash 2000 organic elemental analyser, coupled to a Thermo Scientific Delta V Plus isotope ratio mass spectrometer via a Thermo Scientific Conflo IV gas control unit (detection limit $5 \mu \mathrm{g}$ ). The sand samples (low C and N wt\%) were combusted in a Thermo Finnigan Flash EA 1112 series elemental analyzer, coupled to a Thermo electron Delta Plus XP isotope ratio mass spectrometer via a Thermo Finnigan Conflo III gas control unit (detection limit $15 \mu \mathrm{g}$ ). In-house standards used were: chocolate/egg mixture, Australian National University sucrose, Merck proteinaceous gel and dried lentils, calibrated against International Atomic Energy Agency standards (N1, N2, NBS 
18,19, SMOW and SLAP). The precision for both analytical systems was 0.05 and $0.08 \%$ for $\mathrm{N}$ and $\mathrm{C}$, respectively. Nitrogen $(\mathrm{N})$ isotopic composition is expressed relative to atmospheric $\mathrm{N}$, whereas $\mathrm{C}$ is expressed relative to Pee-Dee Belemnite.

\subsection{C3/C4 plant mass balance}

To broadly gauge the relative proportions of $\mathrm{C}$ input from $\mathrm{C} 4$ and $\mathrm{C} 3$ plants during peat accumulation in Mfabeni, a mass balance equation was used as per Gillson et al. (2004) and Boutton et al. (1998):

$\delta^{13} C_{\text {SOM }}=\left(\delta^{13} C\right.$ C $\left.4_{\text {plants }}\right)(x)+\left(\delta^{13} C C 3_{\text {plants }}\right)(1-x)$

(Equation 1)

Where: $\quad-\delta^{13} \mathrm{C}_{\text {som }}$ bulk stable carbon isotope composition of $\mathrm{C}_{\text {org }}$ in sample $-\delta^{13} C C 4$ plants and $\delta^{13} C C 3_{\text {plants }}$ are the average stable $C$ isotope values from regional C4 (-13.2\%o) and C3 (-27.5\%o) vegetation (Muzuka, 1999). - $\mathrm{x}$ is the proportion of $\mathrm{C}$ from $\mathrm{C} 4$ plant sources and (1-x) the proportion of $\mathrm{C}$ from C3 plants.

\section{Results}

\subsection{Core description}

Core SL6 consists of 7 different sediment types (Fig. 2), dominated by peat with occasional sandy lenses of varying thicknesses: black fine-grained amorphous peat $(810-610 \mathrm{~cm})$, dark brown fine-grained peat with grey sand mottled zones $(610-535 \mathrm{~cm})$, black fine-grained peat with grey sand mottled zones $(535-440 \mathrm{~cm})$, black fine-grained amorphous peat with increasing sandy texture with depth $(440-340 \mathrm{~cm})$, black fined-grained amorphous peat with minimal rootlets $(340-110 \mathrm{~cm}$ ), black fine-grained amorphous peat, with extensive 
rootlets (110 - $61 \mathrm{~cm})$, and dark brown "fibrous" peat transitioning to fine grained black amorphous peat sediments with depth (61-0cm).

171 The peat sediments show an average bulk density of $0.29,0.34,0.28,0.28,0.24{\mathrm{~g} . \mathrm{cm}^{-3} \text { for }}^{-1}$

172 linear sedimentation rate (LSR, see section 3.2 for explanation) stages 1 to 5 , respectively

173 (Table 1). The average core porosity for the dominant peat sediment was calculated to be $174 \quad 0.7$.

\subsection{Age model}

The SL6 basal age recorded at $805 \mathrm{~cm}$ is c. $47.0 \mathrm{kcal}$ yr BP (Table 2; Fig. 3). Peat sediments dominate (Fig. 2) from the base of the core up to the age of c. $31.9 \mathrm{kcal}$ yr BP $(609 \mathrm{~cm})$. Above this a succession of sand lenses cross cut the core, with relatively low C\% up to c. $28.8 \mathrm{kcal}$ yr BP $(540 \mathrm{~cm})$. A fining up transition occurs from "sandy" peat to peaty sediments until a modelled age of c. $14.3 \mathrm{kcal}$ yr BP $(350 \mathrm{~cm})$, after which amorphous peat sediments with increasing rootlet content dominate $(340-61 \mathrm{~cm})$, ending in the top "fibrous" surface peat layer.

The linear sedimentation rates (LSR) calculated for core SL6 suggests several changes in sedimentation regimes (Fig. 4; Table 1). When a trendline is fitted to grouped data points, the lower third of the core, spanning c. 47.0 to c. $32.4 \mathrm{kcal}$ yr BP, displays an average LSR of0.13 mm.yr-1 (LSR Stage 1). The average LSR increases to $0.22 \mathrm{~mm} . \mathrm{yr}^{-1}$ between c. 32.1 and c. $27.9 \mathrm{kcal}$ yr BP (LSR Stage 2), declining to $0.14 \mathrm{~mm} . \mathrm{yr}^{-1} \quad$ (c. 27.6 to c. $20.3 \mathrm{kcal} \mathrm{yr} \mathrm{BP}$; LSR Stage 3) before dropping to its lowest average rate of $0.10 \mathrm{~mm} \cdot \mathrm{yr}^{-1}$ between c. 19.8 and c. $10.4 \mathrm{kcal}$ yr BP (LSR Stage 4). Thereafter, a marked increase in average LSR to $0.29 \mathrm{~mm}^{-\mathrm{yr}^{-}}$

${ }^{1}$ occurs during the Holocene (LSR Stage 5). 


\subsection{Past sedimentation and $C$ measurements}

192

193

194

195

196

197

198

199

200

201

202

203

204

205

206

207

208

209

210

211

212

213

\subsubsection{Mass accumulation rate (MAR)}

MAR in core SL6 fluctuates between a minimum of 20.8 (c. $14.3 \mathrm{kcal}$ yr BP) and a maximum of $103 \mathrm{~g} \cdot \mathrm{m}^{-2} \cdot \mathrm{yr}^{-1}$ (c. $3.5 \mathrm{kcal}$ yr BP) with a total core MAR average of $57.5 \mathrm{~g} \cdot \mathrm{m}^{-2} \cdot \mathrm{yr}^{-1}$ (Fig. 4 and Table 1). LSR stages 1, 3 and 4 display overall lower than core average MAR values of 37.6, 41.4 and $28.1 \mathrm{~g} \cdot \mathrm{m}^{-2} \cdot \mathrm{yr}^{-1}$, respectively, punctuated by abrupt shifts to above core average MAR values for LSR stages 2 and 5 (76.4 and $70.9 \mathrm{~g} \cdot \mathrm{m}^{-2} \cdot \mathrm{yr}^{-1}$, respectively). LSR stage 5 shows the least consistency with overall elevated MAR values, and short intermittent excursions to below average MAR values at c. 7.1, c. 5.3, c. 4.7 and c. $1.4 \mathrm{kcal}$ yr BP.

\subsubsection{Total organic carbon (TOC)}

The sediment TOC of core SL6, for the most part, trends similarly but opposite to MAR records, fluctuating between a minimum of $9.65 \mathrm{~g} \mathrm{C} . \mathrm{m}^{-2}$ (c. $30.4 \mathrm{kcal} \mathrm{yr} \mathrm{BP}$ ) and a maximum of 1600 g C.m-2 (c. $44.6 \mathrm{kcal} \mathrm{yr} \mathrm{BP)} \mathrm{with} \mathrm{a} \mathrm{total} \mathrm{core} \mathrm{average} \mathrm{of} 981$ g C.m-2 (Fig. 4; Table 1). During LSR stage 1, TOC fluctuates dynamically between the core maximum and $327 \mathrm{~g} \mathrm{C} . \mathrm{m}^{-2}$

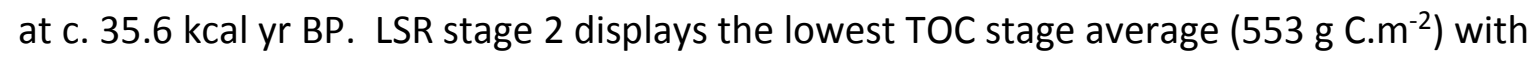
the exception of an abrupt increase of $584 \mathrm{~g} \mathrm{C} . \mathrm{m}^{-2}$ towards the latter part of the stage (28.5 kcal yr BP). LSR stage 3 fluctuates around the core average until a sharp decrease occurs at c. $22.3 \mathrm{kcal}$ yr BP followed by a relatively low TOC values till c. $14.3(350 \mathrm{~cm}) \mathrm{kcal} \mathrm{yr} \mathrm{BP.}$ Thereafter TOC increases in the lead up to and during the Holocene which exhibits the highest stage TOC average (1108 g C.m ${ }^{-2}$; LSR stage 5), , despite sporadic sharp declines associated with increases in MAR at c. $5.3 \mathrm{kcal} \mathrm{yr} \mathrm{BP}$ and c. $7.7 \mathrm{kcal} \mathrm{yr} \mathrm{BP.}$

\subsubsection{Carbon accumulation rate (CAR)}

From the bottom of core SL6 up until c. $10.2 \mathrm{kcal}$ yr BP, the CAR fluctuates below the total 
core average of $22.05 \mathrm{~g} \mathrm{C} \cdot \mathrm{m}^{-2} \cdot \mathrm{yr}^{-1}$ (stages $1-4$ core average $=11.9 \mathrm{~g} \mathrm{C} \cdot \mathrm{m}^{-2} \cdot \mathrm{yr}^{-1}$ ), with the

215 exception of between c. 28.6 and c. $27.9 \mathrm{kcal}$ yr BP where the CAR maximises at just below 28 g C.m $^{-2}$.yr $r^{-1}$ (Fig. 4; Table 1). The lowest CAR values occur between c. 30.4 and c. 30.0 kcal yr BP (LSR stage 2), coinciding with an increase in sand dominated sediments. The top quarter of core SL6 (LSR stage 5) displays an elevated average CAR of $32.3 \mathrm{C} . \mathrm{m}^{-2} \cdot \mathrm{yr}^{-1}$, notwithstanding three sharp declines at c. 7.1, between c. 5.5 and c. 5.3 and c. 1.4 and c. 1.3 kcal yr BP.

\subsection{Elemental and stable isotopes measurements}

\subsubsection{C/N ratio}

The atomic $\mathrm{C} / \mathrm{N}$ ratio for core SL6 displays a range of between 16.9 (c. $1.4 \mathrm{kcal} \mathrm{yr} \mathrm{BP}$ ) and 71.1 (c. $24.2 \mathrm{kcal} \mathrm{yr} \mathrm{BP)}$ with a core average of 40.5 (Fig. 5). The $\mathrm{C} / \mathrm{N}$ ratio at the base starts out below 30.0 , but steadily increases to 57.3 at c. $38.7 \mathrm{kcal}$ yr BP before sharply declining to 37.6 at c. $37.5 \mathrm{kcal}$ yr BP. The C/N signal then stabilises to between 36 and 52 until c. 24.5 kcal yr BP, where a significant positive shift occurs to a maximum of 71.1 , followed by a return to a below core average of 29.9 at c. $17.1 \mathrm{kcal}$ yr BP. Thereafter, the $\mathrm{C} / \mathrm{N}$ signal gradually increases until c. $1.9 \mathrm{kcal}$ yr BP, where it sharply declines from 57.7 to the core minimum value of 16.9 at c. $1.4 \mathrm{kcal} \mathrm{yr} \mathrm{BP.}$

\subsubsection{Stable $\mathrm{N}$ isotopes}

$\delta^{15} \mathrm{~N}$ values for core SL6 range between 1.9 (c. $41.5 \mathrm{kcal}$ yr BP) and -2.9\%o (c. $0.44 \mathrm{kcal}$ yr BP) and show an overall depletion in ${ }^{15} \mathrm{~N}$ up core (Fig. 5). The $\delta^{15} \mathrm{~N}$ signal shifts to enriched ${ }^{15} \mathrm{~N}$ values from the base of the core till the core maximum at c. $41.5 \mathrm{kcal} \mathrm{yr}$ BP. Thereafter, the $\delta^{15} \mathrm{~N}$ signal steadily trends to depleted ${ }^{15} \mathrm{~N}$ values, with the exception of a period of 
enrichment in ${ }^{15} \mathrm{~N}$ between c. 30.0 and c. $24.5 \mathrm{kcal} \mathrm{yr} \mathrm{BP}$, and a sharp positive incursion to enriched ${ }^{15} \mathrm{~N}$ from -1.5 to $0.9 \%$ at c. $1.4 \mathrm{kcal}$ yr BP.

238

239

240

241

242

243

244

245

246

247

248

249

250

251

252

253

254

255

256

257

\subsubsection{Stable $C$ isotopes}

$\delta^{13} \mathrm{C}$ signal fluctuates between a maximum of $-15.5 \%$ (c. $24.2 \mathrm{kcal} \mathrm{yr} \mathrm{BP}$ ) and minimum of 25.3 (c. $9.4 \mathrm{kcal}$ yr BP), with no discernible overall trend (Fig. 5). With the exception of the base interval, the $\delta^{13} \mathrm{C}$ signal becomes enriched in ${ }^{13} \mathrm{C}$ up core from -22.9 to $-17.4 \%$ o between c. 46.6 and c. $38.3 \mathrm{kcal}$ yr BP before sharply decreasing to $-22.3 \%$. Thereafter, the $\delta^{13} \mathrm{C}$ signal increases steadily to the core maximum value at c. $24.2 \mathrm{kcal} \mathrm{yr} \mathrm{BP}$, and then declines again to the core minimum at c. $9.4 \mathrm{kcal}$ yr BP. For the remaining part of the upper core, the $\delta^{13} \mathrm{C}$ signal becomes enriched in ${ }^{13} \mathrm{C}$ through a succession of fluctuating cycles displaying pronounced enrichment shifts in ${ }^{13} \mathrm{C}$ of $4.5 \%$ (c. 8.8 to c. $8.4 \mathrm{kcal}$ yr BP), $8.2 \%$ (c. 6.5 to c. $4.7 \mathrm{kcal} \mathrm{yr} \mathrm{BP)} \mathrm{and} 4.5 \%$ (c. 1.2 to c. $0.15 \mathrm{kcal} \mathrm{yr} \mathrm{BP).}$

\section{Discussion}

\subsection{Sedimentation and carbon accumulation}

Core SL6 returned a basal ${ }^{14} \mathrm{C}$ age of c. $47.0 \mathrm{kcal}$ yr BP $(805 \mathrm{~cm})$, spanning the late Pleistocene and Holocene, positioning it as one of the oldest continuous coastal peatland records globally. According to Strack (2008), low lying coastal peat deposits in the (sub) tropics tend to accumulate faster than their temperate / boreal counterparts, however, most of the extensive coastal peatlands surveyed in SE Asia (Anderson and Muller, 1975; Staub and Esterle, 1994) only originated in the middle to late Holocene after the last sea level transgression. The Mfabeni peatland, therefore, is unique and owes its longevity to the protection against sea level fluctuations, and enhanced groundwater transmissibility 
258 (Grundling et al., 2013) of the adjacent coastal dune corridor (c. 55 kcal yrs BP; Porat and 259 Botha; 2008).

260 The varying LSR, MAR and CAR throughout core SL6 (Fig. 4) are indicative of changes in sedimentation regimes which are ultimately controlled by local climate. The total core LSR of between 0.10 and $0.29 \mathrm{~mm} . \mathrm{yr}^{-1}$ calculated for SL6 compares favourably with the average C accumulation rate reported by Grundling $(2001,2013)$ in the Mfabeni peatland. Peat accumulates when Net Primary Production (NPP) outstrips decomposition (Chimner and Ewel, 2005). In sub-arctic and boreal peatlands, the low to sub-zero temperatures retard microbial decomposition causing peat to accumulate (Francez and Vasander, 1995), notwithstanding the short growing seasons. However in the tropics, peatlands are subject to consistent hot and often humid conditions that are associated with rapid rates of decomposition. Although elevated temperatures facilitate microbial decomposition and rapid turnover of OM in tropical regions, it also increases NPP due to longer growing seasons and relatively higher precipitation, with plant roots mooted as the primary source of peat accumulation in tropical regions (Chen and Twilley, 1999; Chimner et al., 2002). The overriding dominant control on (sub) tropical peat formation is waterlogging, which enables prevailing anaerobic depositional conditions that ultimately retard the rate of decomposition and permits OM rich peat sediments to accumulate (Rieley et al., 1996).

Waterlogging in peatlands results from an in-balance between moisture input and evapotranspiration, facilitated by local geology/ topography, impermeable mineral base layers, basin geomorphology and groundwater input (Cameron et al., 1989). core, spanning the Holocene, averages $32 \mathrm{~g} \mathrm{C} \cdot \mathrm{m}^{-2} \cdot \mathrm{yr}^{-1}$, with the rest of the core averaging 
only $12 \mathrm{~g} \mathrm{C} \cdot \mathrm{m}^{-2} \cdot \mathrm{yr}^{-1}$. Estimates for Holocene CAR for the northern hemisphere peatlands

have been published (Gorham, 1991; Turunen et al., 2002; Charman et al., 2013), with some authors using a statistical model developed by Clymo et al. (1992), to convert long-term apparent $\mathrm{C}$ accumulation (LARCA) rates to contemporary true rate of carbon accumulation (TRACA), with limited success (Gorham, 1991; Clymo et al., 1998). The LARCA average rate calculated for a northern Swedish fen was reported to be $25 \mathrm{~g} \mathrm{C} \cdot \mathrm{m}^{-2} \cdot \mathrm{yr}^{-1}$ (Oldfield et al., 1997) and $24 \mathrm{~g} \mathrm{C.m} \mathrm{m}^{-2} \cdot \mathrm{yr}^{-1}$ for a proximal fen $70 \mathrm{~km}$ away (Nilsson et al., 2008). Gorham (1991), on the other hand, published a global LARCA estimate of $29 \mathrm{~g} \mathrm{C} \cdot \mathrm{m}^{-2} \cdot \mathrm{yr}^{-1}$, which is more representative of the CAR $\left(32 \mathrm{~g} \mathrm{C}^{-\mathrm{m}^{-2}} \cdot \mathrm{yr}^{-1}\right)$ in the Mfabeni peatland during the Holocene.

\subsection{Elemental and isotopic proxies}

Atomic $\mathrm{C} / \mathrm{N}$ ratios are often used as a proxy to delineate $\mathrm{OM}$ sources in lakes and marine environments (Meyers, 1994, 2003; Gälman et al, 2008). In peatlands, the C/N proxy has been employed in conjunction with $\mathrm{C}$ and $\mathrm{N}$ stable isotope signatures to elucidate $\mathrm{OM}$ preservation, redox depositional conditions and biogeochemical processes related to $C$ and N cycling of sedimentary OM (Skrzypek et al., 2008; Jones et al., 2010; Andersson et al., 2012).

Palaeoresearchers commonly employ the $\delta^{15} \mathrm{~N}$ proxy as an indicator for bulk OM source input into lake / marine sediments and changes in palaeoproductivity (Meyers and Ishiwatari, 1993; Meyers, 1997, 2003; Routh et al., 2004; Choudhary et al., 2009). In peatlands, higher plants form the overwhelmingly dominant source of OM input; resulting in up to $95 \%$ of $\mathrm{N}$ originating from the degraded plant OM (Andersson et al., 2012). The premise for the $\mathrm{N}$ isotope bulk OM source proxy is based on the isotopically different sources of inorganic $\mathrm{N}$ available to plants. Plants that receive their $\mathrm{N}$ predominantly from 
soil $\mathrm{N}$ fixers conventionally display $\delta^{15} \mathrm{~N}$ values within a small range (approximately -2 to $+2 \%$ ) analogous to atmospheric $\delta^{15} \mathrm{~N}( \pm 0 \%$ ). In contrast, plants sourcing the majority of their $\mathrm{N}$ through microbially catalysed OM decomposition display characteristically more negative $\delta^{15} \mathrm{~N}$ ranges (ca. -2 to $-8 \%$; Fogel and Cifuentes, 1993; Skrzypek et al., 2008). Bodelier and Laanbroek (2004) suggested that during increased rates of methanogenesis, and by that token increased temperatures and waterlogging in tropical peatlands, the high $\mathrm{N}$ demanding methanogenic bacteria tend to consume large quantities of ${ }^{14} \mathrm{~N}$ to produce a more isotopically light $\mathrm{N}$ source for plants, which ultimately causes the peat $\mathrm{N}$ isotopic signal to become depleted in ${ }^{15} \mathrm{~N}$.

Stable carbon isotope signatures, in conjunction with atomic $\mathrm{C} / \mathrm{N}$ ratios, have also proven to be robust indicators of OM sources, diagenetic alteration and primary production (Meyers and Ishiwatari, 1993; Meyers, 2003). C4 and C3 plants fractionate against ${ }^{13} \mathrm{C}$ differently, which results in significantly more positive bulk $\delta^{13} \mathrm{C}$ values for $\mathrm{C} 4$ plant biomass in comparison with that of C3 plants. Therefore, the $\delta^{13} \mathrm{C}$ signal in peat sediments can serve as an archive for changes in the relative contribution of C4 and C3 plants, which can be related to changes in environmental and climatic conditions (Skrzypek et al., 2008, 2010). The bulk $\delta^{13} \mathrm{C}$ isotopic values in core SL6 demonstrates a strong correlation with concordant isotopic values of the leaf wax $n$-alkanes ( $r=0.88, P=0.01, n=27$; in Baker et al., in preparation), suggesting the major OM source in the Mfabeni sediments are of terrestrial plant origin. A detailed study of how individual plant species identified in Mfabeni could potentially react to changes in moisture and temperature is beyond the scope of this research. We assume, therefore, that these environmental factors have a negligible effect on the $\delta^{13} \mathrm{C}$ value of bulk $\mathrm{OM}$ in comparison with shifts in $\mathrm{C} 3 / \mathrm{C} 4$ vegetation. 
Finch and Hill (2008) undertook an extensive palynological study in the Mfabeni peatland and documented the changes in the pollen record. They observed a local vegetation taxa dominated by varying proportions of Poaceae and Cyperaceae since the late Pleistocene (c. $44 \mathrm{kcal}$ yr BP to present). Even though the Paoceae and Cyperaceae plant families are comprised of both C3 and C4 species, Stock et al., (2004) and Vogel and Fuls (1978) observed a definite geographical distribution between the two photosynthetic pathways in southern Africa. The C4 grasses and sedges occur more abundantly in the north eastern austral summer rainfall areas, while the $\mathrm{C} 3$ species are more dominant in the winter rainfall areas and high altitude regions of the south western Cape and eastern Escarpment. Kotze and $\mathrm{O}^{\prime}$ Connor (2000) did a study of contemporary vegetation within and around wetlands along an altitudinal gradient in the Kwazulu-Natal region. They documented the percentage variations of the two dominant species, namely $\mathrm{C} 3 / \mathrm{C} 4$ grasses and sedges, in wetlands with varying hydrological conditions. The Mongolwane wetland, at $550 \mathrm{~m}$ elevation, recorded relative proportions of $49.2,39.6,9.5$ and $1.7 \%$ for C4 sedges, C3 grasses, C3 sedges and C4 grasses, respectively, in permanently inundated sections, and 57.6, 21.0, 13.2 and $8.2 \%$ for C4 sedges, C4 grasses, C3 grasses and C3 sedges, respectively, in seasonally in undated areas. This represents a shift from 50:50 split between C3 and C4 plant species in permanent wetlands to $\sim 20: 80$ ratio in favour of C4 plant species in seasonal wetlands. Kotze and O'Connor (2000) also recorded an increase to near absolute C4 grasses dominance as a result of moisture reduction in low-lying wetlands.

Throughout core SL6, the C/N ratio does not fall below 20 (Fig. 5), besides at $54 \mathrm{~cm} \mathrm{(17;} \mathrm{c.}$ $1.4 \mathrm{kcal}$ yr BP), reiterating the predominant OM input into the Mfabeni peatland being vascular land plants. The elemental $\mathrm{C}$ and $\mathrm{N}$ wt\% values exhibit a strong correlation 
throughout the core (total core: $r=0.77 ; P=0.01 ; n=196$; refer to Table 3 for individual LSR stages and Fig. 5), which represents a MAR, as opposed to diagenetic relationship for $C$ and N concentrations with depth (Andersson et al., 2012). Kuhry and Vitt (1996) used the elemental $\mathrm{C} / \mathrm{N}$ relationship to explore diagenetic effects in acrotelm and catotelm peat layers. They proposed that in the aerobic acrotelm layer, $\mathrm{N}$ is preferentially lost during $\mathrm{OM}$ breakdown, resulting in increased bulk $\mathrm{C} / \mathrm{N}$ ratio with depth, whereas in the anaerobic catotelm layer, a decrease in $\mathrm{C} / \mathrm{N}$ should be observed as a result of methanogenesis and $\mathrm{N}$ becoming immobile under anoxic conditions. The SL6 C/N ratio shows no overall trends down core, supporting the inference based on the wt\% $\mathrm{C}$ and $\mathrm{N}$ relationship, that diagenetic alteration did not play a major role during overall peat formation in Mfabeni peatland.

The $\delta^{15} \mathrm{~N}$ signal in core SL6 displays a general increasing trend with depth, with values ranging between -2.9 and $1.9 \%$ suggesting the predominant source of bioavailable $\mathrm{N}$ during photosynthesis is $\mathrm{N}$-fixing bacteria and not microbial reworking of $\mathrm{OM}$. In contrast, the $\delta^{13} \mathrm{C}$ profile fluctuates between -25.3 and $-15.5 \%$, inferring an interchangeable source of C3 and C4 plant end members (Fig. 5 and 6). It has been shown that the lighter ${ }^{12} \mathrm{C}$ (Nichols et al., 2009; Jones et al., 2010) and ${ }^{14} \mathrm{~N}$ isotopes (Amundson et al., 2005) are preferential removed during extensive microbial remineralisation, resulting in an enrichment in both the ${ }^{13} \mathrm{C}$ and ${ }^{15} \mathrm{~N}$ isotopes in the remaining soil (and more ${ }^{14} \mathrm{~N}$ available for plant uptake; Bodelier and Laanbroek, 2004). Therefore a significant statistical correlation can be expected between the $\delta^{13} \mathrm{C}, \delta^{15} \mathrm{~N}$ and $\mathrm{C} / \mathrm{N}$ signals in extensively decomposed soils (Engel et al., 2010), or conversely, an insignificant correlation in highly preserved soils where minor isotopic $\mathrm{C}$ and 
LSR stages in core SL6, the statistical relationships can be used to infer the relative degree of SOM preservation / rates of decomposition for each LSR stages.

There is a general absence of any significant correlation between the $\delta^{15} \mathrm{~N}$ and $\delta^{13} \mathrm{C}$ signals (Table 3) in all five of the LSR stages endorsing the Mfabeni sediments as highly preserved. When comparing the $\delta^{13} \mathrm{C}$ and $\mathrm{C} / \mathrm{N}$ signals, a significant correlation is exhibited in LSR stages $1-4$, while the $\delta^{15} \mathrm{~N}$ and $\mathrm{C} / \mathrm{N}$ comparison only shows a significant correlation during LSR stages 2 and 3 . This unbalanced correlation between the isotopic and elemental combinations up core suggests the degree of OM preservation was influenced predominantly by environmental factors during deposition and diagenesis, as opposed to peat maturity (age), permitting us to gauge relative rates of decomposition during each LSR stage, and surmise the environmental factors affecting not only sedimentation but decomposition rates (Engle et al., 2010).

\subsection{Palaeo reconstruction}

\subsubsection{LSR Stage 1 (c. 47.0 - c. 32.4 kcal yr BP)} high average TOC, below average $C$ accumulation (Fig. 4), and relatively low rates of decomposition (Table 3) suggesting a cool and wet period, with extended phases of waterlogging, but slow peat accumulation probably as a result of lower NPP. The $\delta^{15} \mathrm{~N}$ values are comparatively more positive, ranging between -0.4 and $+1.9 \%$, indicating a predominant atmospheric $\mathrm{N}$ fixing source while the $\delta^{13} \mathrm{C}$ signal fluctuates between -22.9 and $-15.8 \%$, representing a C4 plant dominated OM input (Fig. 5). Finch and Hill (2008) found evidence of high frequencies of forest tree pollen, with a locally dominant signal of grasses, and to a lesser extent sedges, between c. 44 and c. $33 \mathrm{kcal}$ yr BP, which they interpreted to represent a cool and wet period. A cooler climate could have resulted in lower rates of 
methanogenesis, and a reduction in bioavailable ${ }^{14} \mathrm{~N}$ (Skrzype et al., 2008; Jones et al., 2010). For the $\delta^{13} \mathrm{C}$ signal, however, the $C$ isotope signature is only significantly influenced by the relative proportions of C3 and C4 plant OM input. Stock et al. (2004) concluded that C4 sedges endemic throughout South Africa appeared to have evolved more as a response to low atmospheric $\mathrm{CO}_{2}$, as opposed to limited nutrient and hydrologic adaptations, which are more typical of the regional $\mathrm{C} 4$ grasses. The shifts in $\delta^{13} \mathrm{C}$ during this stage trends similarly, but opposite to the $\mathrm{CO}_{2}$ records reported in the Byrd ice cores (Stocker, 2000) reinforcing the proposed evolutionary relationship between C4 plants and lower atmospheric $p \mathrm{CO}_{2}$.

Notably, the core TOC maximum occurs in this stage at c. $44.6 \mathrm{kcal}$ yr BP $\left(1600 \mathrm{~g} \mathrm{C}^{-2} \mathrm{~m}^{-2}\right.$, together with another abrupt increase in average TOC values between c. 37.9 and c. 35.9 kcal yr BP, concordant with the A2 and A1 warming event (and Heinrich 5 (H5) and Heinrich $4(\mathrm{H} 4)$ cooling event in the Northern hemisphere) identified by $\delta^{18} \mathrm{O}$ and $\delta^{2} \mathrm{H}$ signals in the Byrd and Vostok ice cores from Antarctica (and GRIP ice core in Greenland; Blunier et al., 1998; Stocker, 2000). Bard et al. (1997) reported an overall $1.6^{\circ} \mathrm{C}$ gradual decline in alkenone proxy sea surface temperatures (SST) from a marine sediment core (MD79257) extracted at $20^{\circ} \mathrm{S}$ in the Mozambique Channel during this same period. However, included in this general decline, two prominent spikes were observed at c. 44.5 and c. $35.5 \mathrm{kcal}$ yr BP, which correspond to the A2 and A1 warming events, respectively (Blunier et al., 1998;

417 Stocker, 2000). Although the stable isotope signature does not definitively reflect the A2 warming event (or $\mathrm{H} 5,44.5 \mathrm{kcal}$ yr BP), a shift of $-4.1 \%$ to more negative $\delta^{13} \mathrm{C}$ values and a decrease in C4 plant contribution (Fig. 6) is observed starting at c. 38 kcal yr BP (A2; H4). This $\delta^{13} \mathrm{C}$ negative shift is followed closely by a negative shift in $\delta^{15} \mathrm{~N}$ values, which suggests 
an increase in microbial sources of ${ }^{14} \mathrm{~N}$ isotopes as a response to the $\mathrm{A} 1$ warming event. It is postulated that the prominent change in physical and geochemical parameters during the

A1 (and A2) warming event was a result of permanent waterlogging and increased contributions from C3 grasses relative to C4 sedges during a period of permanent inundation (Kotze and O'Connor, 2000), accompanied by increased rates of methanogenesis towards the latter part of LSR Stage 1.

\subsubsection{LSR stage 2 (c. 32.1 - c. 27.9 kcal yr BP)}

The next LSR stage (Fig. 4) displays an increased average LSR of $0.22 \mathrm{~mm} . \mathrm{yr}^{-1}$, overall high MAR, low TOC and CAR, which was accompanied by a gradual overall positive trends in $\delta^{13} \mathrm{C}$ and $\delta^{15} \mathrm{~N}$ values (Fig. 5) and an increase in decomposition rates compared to LSR stage 1 (Table 3). These parameters infer a period of minimal water logging at the site, and a shift to sand dominated sedimentation, most likely due to a shift to drier and winder conditions. Conversely, a sharp increase in TOC and C accumulation to above core average values, concordant with more negative $\delta^{15} \mathrm{~N}$ values occurred in the latter part of LSR stage 2 (c. 28.6 to c. $27.9 \mathrm{kcal}$ yr BP), suggesting a short period of wet and warm conditions, in contrast to the general overall trend towards full glacial conditions. The $\delta^{13} \mathrm{C}$ signal, however, continues along an overall positive trend, inferring a continued increase in C4 plant input which can be correlated to overall decreasing $p \mathrm{CO}_{2}$ (compared to the Byrd Ice core; Stocker, 2000). This interpretation is supported by a general decline over the same timescale, punctuated by an abrupt increase of $1^{\circ} \mathrm{C}$ at c. $28 \mathrm{kcal} \mathrm{yr} \mathrm{BP}$ in the MD79257 core derived alkenone SST (Bard et al., 1997), and a decline in forest pollen and switch towards sedge dominated swamp vegetation (Finch and Hill, 2008). Likewise, the Vostok ice core registered a noticeable return to more positive $\delta^{2} \mathrm{H}$ values at c. $28 \mathrm{kcal} \mathrm{yr} \mathrm{BP}$ (Stocker, 2000). Talma and Vogel 444 (1992) calculated late Quaternary ambient temperatures from speleotherm $\delta^{18} \mathrm{O}$ values in 
the Cango Caves $\left(22^{\circ} \mathrm{E}, 33^{\circ} \mathrm{S}\right)$, which is situated in the perennial rainfall region of the southern Cape, South Africa. They observed a slow overall decline in temperature leading up to the LGM (c. 19 to c. $17 \mathrm{kyr} B P$ ), punctuated by a $\sim 1.5^{\circ} \mathrm{C}$ temperature reversal at c. $28.5 \mathrm{kyr}$ BP. It could also be argued that with the large abrupt increase in CAR observed at the conclusion of LSR stage 2, the Mfabeni peatland switched from being a temporary to a seasonally inundated fen resulting in an increase in C4 sedge dominance as reported by Kotze and O'Connor (2000). Partridge (2002) similarly recorded a peak in precipitation levels using a rainfall time series sediment proxy extracted from the Tswaing impact crater lake in north eastern South Africa around c. $28 \mathrm{kcal}$ yr BP, before the onset of full glacial conditions.

\subsubsection{LSR stage 3 (c. 27.6 - c. 20.3 kcal yr BP)}

During LSR stage 3 (Fig. 4), the LSR drops to an average of $0.14 \mathrm{~mm} . \mathrm{yr}^{-1}$ accompanied by below average MAR, average to high TOC and near average CAR until c. $22.7 \mathrm{kcal}$ yr BP, after which a sharp decline in TOC and to a lesser extent CAR is observed. A significant correlation between both $\delta^{15} \mathrm{~N}$ and $\delta^{13} \mathrm{C}$ with C: $\mathrm{N}$ ratio suggests an overall elevated rate of decomposition during the LGM (Table 3). The $\delta^{15} \mathrm{~N}$ and $\delta^{13} \mathrm{C}$ values remain relatively stable until c. $24.2 \mathrm{kcal}$ yr BP. The $\mathrm{N}$ and C stable isotope records subsequently diverge (H2, Fig. 5), the $\delta^{15} \mathrm{~N}$ values become more negative, whereas the $\delta^{13} \mathrm{C}$ and $\mathrm{C} / \mathrm{N}$ ratio values abruptly increase, coincidental with elevated TOC and average CAR. These changing parameters can be interpreted as an initial shift to cooler temperatures and a peak in waterlogging (precipitation) and increased dominance of widespread C4 wetland sedges (Kotze and O'Conner, 2000), before a shift to cooler and drier conditions after c. $23 \mathrm{kcal}$ yr BP. The sharp increase in $\mathrm{C} / \mathrm{N}$ ratio at c. $24.2 \mathrm{k}$ cal yr BP could possibly be due to an increase in peat accumulation, as a result of higher plant preservation during extensive waterlogging 
suggested by the elevated TOC and more subtle increases in the LSR and CAR. Thereafter, the $\delta^{13} \mathrm{C}$ signal steadily decreases, coinciding with a sharp drop in TOC and CAR, which we conclude as an overall increase in relative abundance of C3 grasses, which have an advantage over C4 grasses / sedges at lower growing season temperatures (Sage et al., 1999; Kotze and O' Conner, 2000; Finch and Hill, 2008; Fig. 6). The SST of core MD79257 displayed stable temperatures around $26^{\circ} \mathrm{C}$ until c. $24 \mathrm{kcal}$ yr BP (H2) after which the signal steadily declines towards the lowest core SST of $24.2{ }^{\circ} \mathrm{C}$ at c. $20 \mathrm{kcal}$ yr BP (Bard et al., 1997). The Byrd Antarctic ice core $\delta^{18} \mathrm{O}$ signal oscillates between -41.5 and $-39.0 \%$ until c. $24 \mathrm{kcal}$ yr BP, after which the signal declines to lowest levels for the next c. $3.5 \mathrm{kyr}$ (Blunier et al., 1998). Finch and Hill (2008) observed an abrupt change from swamp sedge to grassland vegetation after c. $24 \mathrm{kcal}$ BP which they interpreted as an abrupt shift to drier, cooler local conditions at the onset of the LGM (c. $24 \mathrm{kcal}$ yr BP) indicated by a sudden increases in Poaceae pollen frequencies and a steady decline in Cyperaceae pollen. Likewise, the Cold Air cave stalagmite located in Makapansgat Valley $\left(24^{\circ} \mathrm{S}, 29^{\circ} \mathrm{E}\right)$ in the summer rainfall area of South Africa recorded drier conditions in conjunction with lower temperatures between $23-21$ kyr (Holmgren et al., 2003).

\subsubsection{LSR Stage 4 (c. 19.8 - c. 10.4 kcal yr BP)}

The lowest core average LSR $\left(0.10 \mathrm{~mm} . \mathrm{yr}^{-1}\right)$ occurs in LSR stage 4 (Fig. 4), corresponding to a period of low MAR, low but steadily increasing TOC and CAR dominated by an abrupt shift to negative $\delta^{13} \mathrm{C}$ values. This trend is accompanied by fluctuating $\delta^{15} \mathrm{~N}$ values near the core average (Fig. 5) and relative reduction in decomposition rates (Table 3). Between c. 14.3 and c. $10.8 \mathrm{kcal}$ yr BP, a sharp overall increase in TOC values occurs, whereas other physical and geochemical parameters remain relatively constant. These observations can be 
Chase et al. (2011) recorded relative dry conditions between c. 19.5 and c. $17.5 \mathrm{kcal}$ yr BP,

interpreted as a continuation of dry and cool late glacial conditions up until c. $15 \mathrm{kcal}$ yr BP, after which an abrupt increase in precipitation and waterlogging occurs. The sharply negative $\delta^{13} \mathrm{C}$ values could have been as a result of increases in C3 grass input which is supported by the sharp decline in the proportion of $\mathrm{C}$ from $\mathrm{C} 4$ plants mass balance at the onset of LSR stage 4 (Fig. 6), and then a switch to C3 swamp forest vegetation after c. $15 \mathrm{kcal}$ yr BP due to the abrupt increase in precipitation. Finch and Hill (2008) documented a continued dominance of grasslands over wetland sedges during this stage, which leads us to speculate that the predominant photosynthetic pathway employed by Poaceae grasses was C3 as a consequence of the better adaptation to lower growing season temperatures and general dry conditions compared to C4 plants (Sage et al., 1999) up to c. $15 \mathrm{kcal}$ yr BP.

Norström et al. (2009) used palynology, and C and N stable isotope proxies to infer a cool and dry climate between 16 and $14.3 \mathrm{kyr}$, then a shift to more humid conditions culminating at $13.2 \mathrm{kyr}$ before returning to drier conditions in the Braamhoek peatland $\left(28^{\circ} \mathrm{S}, 29^{\circ} \mathrm{E}\right)$. Talma and Vogel (1992) recorded a reversal of the generally declining ambient air temperatures in the Cango cave speleothem after c. $15.5 \mathrm{kyr}$ BP, with the temperature steadily increasing up until stalagmite growth ceased at c. $13.8 \mathrm{kyr}$ BP. The Cold Air cave stalagmite $\delta^{18} \mathrm{O}$ signature inferred drier and cooler conditions around c. $19.5-17.5$ and c. 15 - 13.5 kyr, with warming interludes (Holmgren et al., 2003), while biomarker and stable isotope proxies from Lake Tswaing $\left(25^{\circ} \mathrm{S}, 28^{\circ} \mathrm{E}\right)$ suggested the period between c. 14 and c. $10 \mathrm{kcal}$ yr BP experienced increased temperatures and moisture (Kristen et al., 2010).

514 followed by an increase in moisture up to the early Holocene in hyrax midden deposits 515 located in the winter rainfall zone of the SW Cape, with the exception of a conspicuous 
period of drier conditions concomitant with the Younger Dryas (YD). On the contrary,

Schefusz et al. (2011) observed large inputs of terrestrial sedimentary and plant input into the Zambezi catchment area ( $\left.18^{\circ} 33.9^{\prime} \mathrm{S}, 37^{\circ} 22.8^{\prime} \mathrm{E}\right)$ during the $\mathrm{H} 1$ and $\mathrm{YD}$ northern hemisphere cold events, indicating significant increases in adjacent continental austral

520 summer rainfall precipitation, while the proximal Mozambique channel MD79257 core

521 alkenone SST recorded a warming trend after c. 15 kyr BP (H1; Bard et al., 1997). ice cores, and documented asynchronous responses to climate change between the two latitudinal hemispheres during the last deglaciation. The similarity between these trends in core SL6 and other regional climate records implies that the Mfabeni peat deposit faithfully recorded both regional and global late glacial climatic events and displays a comparable opposite phasing in trend and magnitude when compared to northern hemisphere Heinrich and YD climate events.

\subsubsection{LSR stage 5 (c. 10.2 kcal yr BP - present)}

530 The transition to interglacial conditions at the Pleistocene / Holocene boundary displays a

531 prominent shift to highly fluctuating climatic conditions. Gasse (2000) concluded that

532 dramatic Holocene hydrological changes documented in low latitudes on the African continent appear to rival fluctuations observed during the preceding glacial period. The LSR stage 5 is represented by elevated and highly variable sedimentation, displaying the highest LSR stage average $\left(0.29 \mathrm{~mm} . \mathrm{yr}^{-1}\right)$, accompanied by high MAR, overall high TOC and CAR (Fig. 4), with an ever decreasing $\delta^{15} \mathrm{~N}$ and fluctuating $\delta^{13} \mathrm{C}$ signature (Fig. 5). The lack of any significant correlations between either of the stable isotopes and elemental ratio, suggests low rates of decomposition during the Holocene (Table 3). These parameters can be 
interpreted as significant increases in humidity and temperatures typical of an interglacial period, punctuated by a collection of millennial-scale cooling events. Three abrupt excursions to low TOC and CAR values occur at c. 7.1, c. 5.3 and c. $1.4 \mathrm{kcal}$ yr BP, which coincide with decreases in Mozambique Channel alkenone and Zambezi delta TEX ${ }_{86}$-derived SST (Bard et al., 1997; Schefusz et al., 2011), and signs of general aridity in the Kalahari Desert (Stokes et al., 1997). Norström et al. (2009) recorded similar large oscillations in the Braamhoek wetland proxies that are in general agreement with the Mfabeni peatland parameters, with the exception of between 7.5 and 2.5 ka which indicate a relatively dry and warm period, whereas core SL6 recorded overall elevated CAR values, excluding the two millennial-scale drying events at c. 7 and c. 5.3 kcal yr BP. Norström et al. (2009) however did stipulate that this time period can only be used to infer general palaeoenvironmental conditions due to the comparative low rate of peat accumulation and low chronological resolution in the Braamhoek record.

After c. $10.5 \mathrm{kcal}$ yr BP, the CAR abruptly increases while the $\delta^{13} \mathrm{C}$ record displays the minimum core value (-25.3\%; c. 9.4 kcal yr BP) and lowest C4 plant C contribution (Fig. 6) suggesting a significant increase in local precipitation and C3 plant abundance in and around the Mfabeni peatland. The palynology record showed rapidly increasing Podocarpus forest (C3) pollen after c. $11 \mathrm{kcal}$ yr BP, which is interpreted to represent a period of cool and wet

557 conditions (Finch and Hill, 2008). In contrast, Valsecchi et al. (2013) documented a shift from Protea-type pollen to arboreal pollen and attributed the change to warmer and wetter conditions in the winter rainfall fynbos area of the south Western Cape. The Cold Air cave stalagmite returned the lowest $\delta^{13} \mathrm{C}$ values at c. $9 \mathrm{kyr}$, indicating a significant increase in C3 plant influence on the precipitating aragonite (Holmgren et al., 2003). At c. 9 kcal yr BP, the 
$\delta^{13} \mathrm{C}$ values reverse their decreasing trend and rapidly become more positive, peaking at c. $8.4 \mathrm{kcal}$ yr BP, after which the signal returns to more negative values up until c. $7.2 \mathrm{kcal}$ yr BP (first of the millennium scale cooling events), emulated by similar trending TOC and CAR. Finch and Hill (2008) documented a rapid increase in swamp forest vegetation, with sustained levels of Podocarpus pollen, during the Holocene Altithermal (c. 8 to c. $6 \mathrm{kcal} \mathrm{yr}$ $\mathrm{BP})$, which they interpreted to signify a warming trend with high precipitation levels, supported by a corresponding $0.6{ }^{\circ} \mathrm{C}$ increase in the Mozambique Channel core SST data at c. 9 kcal yr BP (Bard et al., 1997). The enriched ${ }^{13} \mathrm{C}$ signal at c. $8.4 \mathrm{kcal} \mathrm{yr} \mathrm{BP}$, could possibly be a result of a spike in $\mathrm{C} 4$ wetland sedge populations (Fig 6) contributing to the enrichment of ${ }^{13} \mathrm{C}$ during a brief period of intensive waterlogging in the peatland, reinforced by a peak in levels of concordant SL6 CAR (Fig. 4). The $\delta^{13} \mathrm{C}$ signal returns steadily to more negative values up until c. $7 \mathrm{kcal}$ yr BP, suggesting a return to swamp forest (C3) dominance, and humid and warm climatic conditions, supported by increases in TOC up until c. 7 kcal yr BP cooling event. Pudsey and Evans (2001) studied changes in glacial till deposits from floating ice sheets at the edge of the Antarctic Peninsula. They documented large deglaciation in the northern James Ross Island, and proposed the full disappearance of the George VI Ice shelf c. $6.5 \mathrm{kyr} \mathrm{BP}$, signifying a warming trend in Antarctic. The Mfabeni $\delta^{13} \mathrm{C}$ signal increases by more than c. 5\%, coinciding with a decrease in $\delta^{15} \mathrm{~N}$ values, between c. 7 and c. $6 \mathrm{kcal}$ yr BP inferring a shift to C4 sedge dominated plant OM input (Kotze and O'Conner, 2000 and Fig. 6) and increased methanogenesis. These signatures indicate a short wet period before a shift to cool dry conditions at the second millennium-scale c. $5.3 \mathrm{kcal}$ yr BP cooling event, delineated by the abrupt decrease in TOC and CAR. After c. 6 kcal yr BP, Finch and Hill (2008) observed a steady decline in the abundance of Podocarpus forest pollen and an 
increase in Poaceae and Cyperaceae frequency, indicating a move to grassland / savannah dominance, and inferred a cooling and drying trend towards the middle Holocene.

Relatively more positive $\delta^{13} \mathrm{C}$ values occur between c. 5 to c. $3 \mathrm{kcal}$ yr BP, coinciding with elevated TOC and CAR and continuance of wetland C4 sedge dominance (Finch and Hill, 2008; Fig. 6), signalling a return to warm and moist conditions. Anthropogenic farming practices become apparent from the palynology record after c. 5 kcal yr BP, specifically attributed by Finch and Hill (2008) to the decline in Podocarpus (C3) forests which could have artificially elevated the $\delta^{13} \mathrm{C}$ climate signal. As a consequence, bulk parameters need to be interpreted with caution from c. $5 \mathrm{kcal}$ yr BP as human influence on the palaeoenvironment signal increased. An overall $\mathrm{C} 4$ peatland signature of the $\delta^{13} \mathrm{C}$ trend and a shift to more negative $\delta^{15} \mathrm{~N}$ up until c. $1.4 \mathrm{kcal}$ yr BP suggests the continued dominance of C4 sedge input (and perhaps anthropogenic forest thinning) due to extensive waterlogging. Finch and Hill (2008) concluded an increase in savannah / grassland pollen to infer a drying trend from c. $3 \mathrm{kcal}$ yr BP to present. However, we interpret core SL6 data to suggest a warming and moist trend over this period (with the exception of the $1.4 \mathrm{kcal}$ yr BP cooling event) as indicated by ever decreasing $\delta^{15} \mathrm{~N}$ and overall positive $\delta^{13} \mathrm{C}$ signals during this same period, signalling waterlogged conditions. The last of the abrupt cooling/drying events (c. $1.4 \mathrm{kcal}$ yr BP) occurs in conjunction with a prominent decrease in both TOC and CAR, a positive $2.4 \%$ o deviation in $\delta^{15} \mathrm{~N}$ and an initial increase, followed by a decrease in $\delta^{13} \mathrm{C}$ values. The changes in the proxy parameters indicate that this abrupt cooling event reduced the rate of methanogensis, reducing the amount of bioavailable ${ }^{14} \mathrm{~N}$ and an increase in C4 grass input (Fig. 6) in response to sudden and brief period of dry conditions. The swift return to the more elevated TOC and CAR and the lowest $\delta^{15} \mathrm{~N}$ core values, 
accompanied by oscillating $\delta^{13} \mathrm{C}$ signal infers a return to cyclical climate conditions and once again highlights the extreme climatic fluctuations characteristic of the Holocene, both regionally and globally (Gasse, 2000; Mayewski et al., 2004).

The Mfabeni record's overall opposite environmental response to better known climatic events in the Northern hemisphere suggests an anti-phase coupling to the southern hemisphere (Figs. 4 and 5). Core SL6 shows a trend in both physical and geochemical parameters towards increased $\mathrm{C}$ accumulation during cold Heinrich events (particularly $\mathrm{H} 5$ to $\mathrm{H} 2$ and $\mathrm{YD})$, suggesting elevated precipitation, and arguably temperatures, which is in direct contrast to findings from the northern hemisphere records. Varying degrees of anti-

617 phased interhemisphere coupling has also been observed by other authors (Bard et al., 1997; Blunier et al., 1998; Schmittner et al., 2003; Chase et al., 2011; Schefusz et al., 2011) with several different mechanisms for climate forcing postulated; signalling a crucial requirement for additional regional palaeoenvironment studies to corroborate or challenge these hypotheses.

\section{Conclusions}

We employed several known geochemical indicators of peat forming processes and related them to changes in past primary production, OM preservation, OM sources and digenetic alteration after deposition. By relating the bulk parameters to physical and biogeochemical processes, we were able to reconstruct the palaeoenvironment that controlled peat formation at the Mfabeni peatland and hypothesise the probable climate on the north east coast of South Africa since the late Pleistocene. We established that the Mfabeni peat sediments have undergone minimal diagenetic alteration, confirming the archive's high degree of preservation and accurate recording of palaeoenvironmental conditions. We 
631

632

633

634

635

636

637

638

639

640

641

642

643

644

645

646

647

648

649

650

651

652

653

surmise the following sequence of palaeoenvironmental conditions and their climatic controls from c. $47 \mathrm{kcal}$ yr BP to present:-

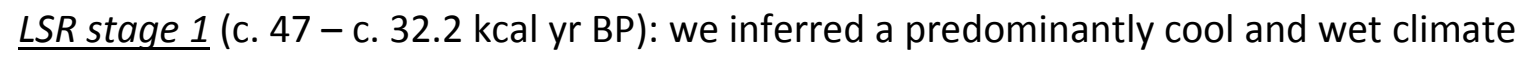
with extensive waterlogged but low NPP, and C4 plant dominant OM source assemblage, punctuated by two short warming events, A2 (c. $44.5 \mathrm{k}$ cal yr BP) and A1 (c. $37 \mathrm{kcal}$ yr BP). The latter events were delineated by elevated TOC attributed to increased NPP and extensive waterlogging. LSR stage 2 (c. 32.2 to c. $27.6 \mathrm{kcal}$ yr BP): a distinct period of sand dominated deposition as a result of negligible waterlogging, suggesting dry and windy conditions, followed by a brief period of warm and wet conditions (c. $28 \mathrm{kcal} \mathrm{yr} \mathrm{BP}$ ) indicated by an abrupt increases in CAR and C4 sedge swamp vegetation abundance. $\underline{L S R}$ stage 3 (c. 27.6 - c. $20.3 \mathrm{kcal}$ yr BP): began with cool and wet conditions with a peak in waterlogging at c. $24 \mathrm{kcal}$ yr BP represented by high TOC and prevailing C4 sedge assemblage. After c. $23 \mathrm{kcal}$ yr BP (LGM), an abrupt change to dry and cool conditions indicated by a sharp drop in TOC and steady increase in C3 grasses relative to C4 sedges as waterlogging receded. $\underline{\text { LSR stage } 4}$ (c. 20.3 - c. $10.4 \mathrm{kcal}$ yr BP): continuance of cool and dry conditions inferred by limited waterlogging and strong C3 grassland signature until c. $15 \mathrm{kcal}$ yr BP, after which, increases in waterlogging and precipitation during waning of the ACR and lead up to the Pleistocene/Holocene boundary. This trend further accentuates the apparent opposite climate phasing between the Northern and southern hemispheres. LSR stage 5 (c. $10.4 \mathrm{kcal}$ yr BP - present): the Holocene epoch is characterized by fluctuations between pervasive wet and warm to cool / dry interglacial conditions, with intermittent abrupt millennial-scale cooling / dry events (c. 7.1, c. 5.3, c. 1.4 kcal yr BP). The MAR, TOC and CAR values are distinctly elevated, with large abrupt magnitudes of variability accompanied by 
654

655

656

657

658

659

660

661

662

663

664

665

666

667

668

669

670

671

672

673

frequent changes between C3 and C4 plant assemblages in comparison to the late glacial period.

In this study, we delineated the Mfabeni peat sequence to produce a high resolution record of past local hydrology and bulk plant assemblages, and by using these signals, we inferred regional climate variability since the Late Pleistocene. There has long been a quest amongst palaeoclimatologists to understand the interhemispheric climate coupling relationship. The Mfabeni archive suggests an anti-phase link between southern Africa and the Northern hemisphere, most notably during $\mathrm{H} 5$ to $\mathrm{H} 2$ and $\mathrm{YD}$ events. Many more analogous palaeoclimate studies need to be undertaken to firm up our understanding of the triggers and change mechanisms responsible for LGM climate variability in southern Africa.

\section{Acknowledgments}

Alistair Clulow helped facilitate field access and site identification. A Russian peat corer was loaned to the project by Piet-Louis Grundling. iSimangaliso Authority and Ezemvelo KZN Wildlife granted access and sampling permission. The following people assisted with laboratory set up, equipment, protocols and analysis: Esmé Spicer, Cynthia SanchezGarrido, Renata Smit, Ian Newton, Lena Lundman, Tomaz Gozlar, Eric Ward and Megan Hill. Nikolai Pedentchouk and Michael Meadows gave valuable manuscript input. The project was supported through a bilateral funding agreement by the Swedish Research Link-South Africa program. Student support was supplied by the National Research Foundation and InKaba yeAfrica. This is an Inkaba ye Africa publication no. 78 and AEON publication no. 118. 


\section{References}

Amundson, R., Austin, A.T., Schuur, E.A.G., Yoo, K., Matzek, V., Kendall, C., Uebersax, A., Brenner, D. \& Baisden, W.T., 2003. Global patterns of the isotopic composition of soil and plant nitrogen. Global Biogeochemical Cycles 17(1), 31-41.

Anderson, J.A.R., Muller, J., 1975. Palynological study of a Holocene peat and a Miocene coal deposit from NW Borneo. Review of Palaeobotany and Palynology 19 (4), 291-317.

Andersson, R.A., Meyers, P., Hornibrook, E., Kuhry, P., Mörth, C., 2012. Elemental and isotopic carbon and nitrogen records of organic matter accumulation in a Holocene permafrost peat sequence in the east European Russian arctic. Journal of Quaternary Science $27(6)$, 545-552.

Bard, E., Rostek, F., Sonzogni, C., 1997. Interhemispheric synchrony of the last deglaciation inferred from alkenone palaeothermometry. Nature 385 (6618), 707-710.

Bate, G.C., Taylor, R.H., 2008. Sediment salt-load in the St Lucia Estuary during the severe drought of 2002-2006. Environmental Geology 55 (5), 1089-1098.

Blaauw, M., Christeny, J.A., 2011. Flexible paleoclimate age-depth models using an autoregressive gamma process. Bayesian Analysis 6 (3), 457-474.

Blunier, T., Chappellaz, J., Schwander, J., Dällenbach, A., Stauffer, B., Stocker, T.F., Raynaudt, D., Jouzel, J., Clausen, H.B., Hammer, C.U., Johnsen, S.J., 1998. Asynchrony of Antarctic and Greenland climate change during the last glacial period. Nature 394 (6695), 739743. 
694

695

696

697

698

699

700

701

702

703

704

705

706

707

708

709

710

711

712

713

714

Bodelier, P.L.E., Laanbroek, H.J., 2004. Nitrogen as a regulatory factor of methane oxidation in soils and sediments. FEMS Microbial Ecology 47 (3), 265-277.

Botha, G., Porat, N., 2007. Soil chronosequence development in dunes on the southeast African coastal plain, Maputaland, South Africa. Quaternary International 162-163, 111-132.

Boutton, T.W., Archer, S.R., Midwood, A.J., Zitzer, S.F., Bol, R., 1998. $\delta 13 C$ values of soil organic carbon and their use in documenting vegetation change in a subtropical savanna ecosystem. Geoderma 82(1-3), 5-41.

Brock, F., Higham, T., Ditchfield, P., Ramsey, C.B., 2010. Current pretreatment methods for ams radiocarbon dating at the oxford radiocarbon accelerator unit (orau). Radiocarbon $52(1), 103-112$.

Cameron, C.C., Esterle, J.S., Palmer, C.A., 1989. The geology, botany and chemistry of selected peat-forming environments from temperate and tropical latitudes. International Journal of Coal Geology 12 (1-4), 105-156.

Charman, D.J., Beilman, D.W., Blaauw, M., Booth, R.K., Brewer, S., Chambers, F.M., Christen, J.A., Gallego-Sala, A., Harrison, S.P., Hughes, P.D.M., Jackson, S.T., Korhola, A., Mauquoy, D., Mitchell, F.J.G., Prentice, I.C., Van Der Linden, M., De Vleeschouwer, F., Yu, Z.C., Alm, J., Bauer, I.E., Corish, Y.M.C., Garneau, M., Hohl, V., Huang, Y., Karofeld, E., Le Roux, G., Loisel, J., Moschen, R., Nichols, J.E., Nieminen, T.M., MacDonald, G.M., Phadtare, N.R., Rausch, N., Sillasoo, U., Swindles, G.T., Tuittila, E.-., Ukonmaanaho, L., Väliranta, M., Van Bellen, S., Van Geel, B., Vitt, D.H., Zhao, Y., 2013. Climate-related 

$10(2), 929-944$

717

Chase, B.M., Quick, L.J., Meadows, M.E., Scott, L., Thomas, D.S. \& Reimer, P.J., 2011. Late glacial interhemispheric climate dynamics revealed in South African hyrax middens. Geology 39 (1), 19-22.

Chase, B.M., Meadows, M.E., 2007. Late Quaternary dynamics of southern Africa's winter rainfall zone. Earth-Science Reviews 84 (3-4), 103-138.

Chen, R., Twilley, R.R., 1999. A simulation model of organic matter and nutrient accumulation in mangrove wetland soils. Biogeochemistry 44 (1), 93-118.

Chimner, R.A., Ewel, K.C., 2005. A tropical freshwater wetland: II. Production, decomposition, and peat formation. Wetlands Ecology and Management 13 (6), 671684.

Chimner, R.A., Cooper, D.J., Parton, W.J., 2002. Modeling carbon accumulation in Rocky mountain fens. Wetlands $22(1), 100-110$.

Choudhary, P., Routh, J., Chakrapani, G.J., 2009. An environmental record of changes in sedimentary organic matter from Lake Sattal in Kumaun Himalayas, India. Science of the Total Environment 407 (8), 2783-2795.

Clulow, A.D., Everson, C.S., Mengistu, M.G., Jarmain, C., Jewitt, G.P.W., Price, J.S., Grundling, P., 2012. Measurement and modelling of evaporation from a coastal wetland in Maputaland, South Africa. Hydrology and Earth System Sciences 16 (9), 3233-3247. 
Clymo, R.S., 1992. Models of peat growth. Suo 43 (4-5), 127-136.

736

737

Clymo, R.S., Turunen, J., Tolonen, K., 1998. Carbon accumulation in peatland. Oikos 81 (2), 368-388.

Czernik, J., Goslar, T., 2001. Preparation of graphite targets in the Gliwice radiocarbon laboratory for $\mathrm{AMS}^{14} \mathrm{C}$ dating. Radiocarbon 43 (2), 283-291.

Engel, Z., Skrzypek, G., Paul, D., Drzewicki, W., Nývlt, D., 2010. Sediment lithology and stable isotope composition of organic matter in a core from a cirque in the Krkonoše Mountains, Czech Republic. Journal of Paleolimnology 43 (4), 609-624.

Finch, J.M., 2005. Late Quaternary palaeoenvironments of the Mfabeni peatland, northern Kwazulu Natal. MSc Thesis, University of KwaZulu-Natal, Pietermaritzburg.

Finch, J.M., Hill, T.R., 2008. A late Quaternary pollen sequence from Mfabeni Peatland, South Africa: Reconstructing forest history in Maputaland. Quaternary Research 70 (3), $442-450$.

Francez, A.J., Vasander, H., 1995. Peat accumulation and peat decomposition after human disturbance in French and Finnish mires. Acta Oecologica 16 (5), 599-608.

Fogel, M.L., Cifuentes, L.A., 1993. Isotope fractionation during primary production. Organic geochemistry: Principles and applications, 73-98.

Gälman, V., Rydberg, J., De-Luna, S.S., Bindler, R., Renberg, I., 2008. Carbon and nitrogen loss rates during aging of lake sediment: Changes over 27 years studied in varved lake sediment. Limnology and Oceanography 53 (3), 1076-1082. 
Gasse, F., 2000. Hydrological changes in the African tropics since the Last Glacial Maximum. Quaternary Science Reviews 19 (1-5), 189-211.

Gasse, F., Chalié, F., Vincens, A., Williams, M.A.J., Williamson, D., 2008. Climatic patterns in equatorial and southern Africa from 30,000 to 10,000 years ago reconstructed from terrestrial and near-shore proxy data. Quaternary Science Reviews 27 (25-26), 23162340.

Gillson, L., Waldron, S., Willis, K.J., 2004. Interpretation of soil $\delta^{13} \mathrm{C}$ as an indicator of vegetation change in African savannas. Journal of Vegetation Science 15 (3), 339-350.

Gorham, E., 1991. Northern peatlands: role in the carbon cycle and probable responses to climatic warming. Ecological Applications 1 (2), 182-195.

Goslar, T., Czernik, J., Goslar, E., 2004. Low-energy ${ }^{14}$ C AMS in Poznań Radiocarbon Laboratory, Poland. Nuclear Instruments and Methods in Physics Research Section B: Beam Interactions with Materials and Atoms (223-224), 5-11.

Grundling, P.L., 2001. The Quaternary peat deposits of Maputaland, Northern KwazuluNatal, South Africa: categorisation, chronology and utilisation. MSc Thesis, University of Johannesburg.

Grundling, P., Grootjans, A.P., Price, J.S., Ellery, W.N., 2013. Development and persistence of an African mire: How the oldest South African fen has survived in a marginal climate. Catena $110,176-183$. 
Hemming, S.R., 2004. Heinrich events: Massive late Pleistocene detritus layers of the North Atlantic and their global climate imprint. Reviews of Geophysics 42 (1), 1-43.

Holmgren, K., Lee-Thorp, J.A., Cooper, G.R.J., Lundblad, K., Partridge, T.C., Scott, L., Sithaldeen, R., Siep Talma, A., Tyson, P.D., 2003. Persistent millennial-scale climatic variability over the past 25,000 years in southern Africa. Quaternary Science Reviews 22 (21-22), 2311-2326.

Holzkämper, S., Holmgren, K., Lee-Thorp, J., Talma, S., Mangini, A., Partridge, T., 2009. Late Pleistocene stalagmite growth in Wolkberg Cave, South Africa. Earth and Planetary Science Letters 282 (1-4), 212-221.

Hua, Q., Barbetti, M., 2004. Review of tropospheric bomb C-14 data for carbon cycle modelling and age calibration purposes. Radiocarbon, 46 (3), 1273-1298.

Immirzi, C.P., Maltby, E., Clymo, R.S., 1992. The global status of peatlands and their role in carbon cycling: A report for the Friends of the Earth. Wetlands Ecosystems Research Group, Department of Geography, University of Exeter, London.

Jedrysek, M., Skrzypek, G., 2005. Hydrogen, carbon and sulphur isotope ratios in peat: The role of diagenesis and water regimes in reconstruction of past climates. Environmental Chemistry Letters 2 (4), 179-183.

Jones, M.C., Peteet, D.M., Sambrotto, R., 2010. Late-glacial and Holocene $\delta^{15} \mathrm{~N}$ and $\delta^{13} \mathrm{C}$ variation from a Kenai Peninsula, Alaska peatland. Palaeogeography, Palaeoclimatology, Palaeoecology 293 (1-2), 132-143. 
Kelbe, B.E., Rawlins, B.K., Nomquphu, W., 1995. Geohydrological modelling of Lake St Lucia. Report, University of Zululand, KwaDlangezwa 3886 KwaZulu-Natal.

Kotze, D.C., O'Connor, T.G., 2000. Vegetation variation within and among palustrine wetlands along an altitudinal gradient in KwaZulu-Natal, South Africa. Plant Ecology 146 (1), 77-96.

Kristen, I., Wilkes, H., Vieth, A., Zink, K., Plessen, B., Thorpe, J., Partridge, T.C., Oberhänsli, H., 2010. Biomarker and stable carbon isotope analyses of sedimentary organic matter from Lake Tswaing: Evidence for deglacial wetness and early Holocene drought from South Africa. Journal of Paleolimnology 44 (1), 143-160.

Kuhry, P., Vitt, D.H., 1996. Fossil carbon/nitrogen ratios as a measure of peat decomposition. Ecology 77 (1), 271-275.

Lee-Thorp, J., Holmgren, K., Lauritzen, S.E., Linge, H., Moberg, A., Partridge, T., Stevenson, C., Tyson, P., 2001. Rapid climate shifts in the southern African interior throughout the mid to late Holocene. Geophysical Research Letters 28 (23), 4507-4510.

Lubke, R.A., Moll, J.B., Avis, A.M., 1992. Rehabilititaion ecology in coastal and environmental services: eastern shores of Lake St Lucia. Kingsa/Tojan lease area special reports 1, biophysical environment, Council of Scientific and Industrial Research, Pretoria, South Africa.

Mayewski, P.A., Rohling, E.E., Stager, J.C., Karlén, W., Maasch, K.A., Meeker, L.D., Meyerson, E.A., Gasse, F., van Kreveld, S., Holmgren, K., Lee-Thorp, J., Rosqvist, G., Rack, F., 

Quaternary Research 62 (3), 243-255.

McCormac, F.G., Hogg, A.G., Blackwell, P.G., Buck, C.E., Higham, T.F.G., Reimer, P.J., 2004. SHCal04 southern Hemisphere calibration, 0-11.0 cal kyr BP. Radiocarbon 46 (3), 10871092.

Meadows, M.E., Baxter, A.J., Parkington, J., 1996. Late Holocene environments at Verlorenvlei, Western Cape Province, South Africa. Quaternary International 33 (1), 81 95.

Meadows, M.E., Baxter, A.J., 1999. Late Quaternary palaeoenvironments of the

Meyers, P.A., 1997. Organic geochemical proxies of paleoceanographic, paleolimnologic,

Meyers, P.A., 2003. Applications of organic geochemistry to paleolimnological reconstructions: A summary of examples from the Laurentian Great Lakes. Organic Geochemistry 34 (2), 261-289.

Meyers, P.A., 1994. Preservation of elemental and isotopic source identification of sedimentary organic matter. Chemical Geology 114 (3-4), 289-302. 
Meyers, P.A., Ishiwatari, R., 1993. Lacustrine organic geochemistry-an overview of indicators of organic matter sources and diagenesis in lake sediments. Organic Geochemistry $20(7), 867-900$.

Mucina, L., Adams, J.B., Knevel, I.C., Rutherford, M.C., Powrie, L.W., Bolton, J.J., van der Merwe, J.H., Anderson, R.J., Bornman, T.G., le Roux, A., Janssen, J.A.M., 2006. Coastal Vegetation of South Africa, in: Mucina, L., Rutherford, M.C. (Eds.), The vegetation of South Africa, Lesotho and Swaziland. South African National Biodiversity Institute, Pretoria, pp. 658-696.

Muzuka, A.N.N., 1999. Isotopic compositions of tropical East African flora and their potential as source indicators of organic matter in coastal marine sediments. Journal of African Earth Sciences 28 (3), 757-766.

Neumann, F.H., Scott, L., Bousman, C.B., van As, L., 2010. A Holocene sequence of vegetation change at Lake Eteza, coastal KwaZulu-Natal, South Africa. Review of Palaeobotany and Palynology 162 (1), 39-53.

Neumann, F.H., Stager, J.C., Scott, L., Venter, H.J.T., Weyhenmeyer, C., 2008. Holocene vegetation and climate records from Lake Sibaya, KwaZulu-Natal (South Africa). Review of Palaeobotany and Palynology 152 (3-4), 113-128.

Nichols, J.E., Walcott, M., Bradley, R., Pilcher, J., Huang, Y., 2009. Quantitative assessment of precipitation seasonality and summer surface wetness using ombrotrophic sediments from an Arctic Norwegian peatland. Quaternary Research 72 (3), 443-451. 
Preston-Whyte, R.A, Tyson, P.D., 1998. The atmosphere and weather of southern Africa.

Nilsson, M., Sagerfors, J., Buffam, I., Laudon, H., Eriksson, T., Grelle, A., Klemedtsson, L., Weslien, P., Lindroth, A., 2008. Contemporary carbon accumulation in a boreal oligotrophic minerogenic mire, a significant sink after accounting for all C-fluxes. Global Change Biology 14 (10), 2317-2332.

Norström, E., Scott, L., Partridge, T.C., Risberg, J., Holmgren, K., 2009. Reconstruction of environmental and climate changes at Braamhoek wetland, eastern escarpment South Africa, during the last 16,000 years with emphasis on the Pleistocene-Holocene transition. Palaeogeography, Palaeoclimatology, Palaeoecology 271 (3-4), 240-258.

Oldfield, F., Thompson, R., Crooks, P.R.J., Gedye, S.J., Hall, V.A., Harkness, D.D., Housley, R.A., McCormac, F.G., Newton, A.J., Pilcher, J.R., Renberg, I., Richardson, N., 1997. Radiocarbon dating of a recent high latitude peat profile: Stor Amyran, northern Sweden. Holocene 7 (3), 283-290.

Page, S.E., Rieley, J.O., Banks, C.J., 2011. Global and regional importance of the tropical peatland carbon pool. Global Change Biology 17 (2), 798-818.

Partridge, T.C., 2002. Were Heinrich events forced from the southern hemisphere? South African Journal of Science 98 (1-2), 43-46.

Porat, N., Botha, G., 2008. The luminescence chronology of dune development on the Maputaland coastal plain, southeast Africa. Quaternary Science Reviews 27 (9-10,) 1024-1046.

872 Oxford University Press, South Africa. 
Pudsey, C.J., Evans, J., 2001. First survey of Antarctic sub-ice shelf sediments reveals midHolocene ice shelf retreat. Geology 29 (9), 787-790.

Reimer, P.J., Baillie, M.G.L., Bard, E., Beck, J.W., Blackwell, P.G., Buck, C.E., Burr, G.S., Edwards, R.L., Friedrich, M., Guilderson, T.P., 2006. Comment on: Radiocarbon calibration curve spanning 0 to 50,000 years BP based on paired 230Th/234U/238U and ${ }^{14} \mathrm{C}$ dates on pristine corals by RG Fairbanks et al., 2005. Quaternary Science Reviews 24, 1781-1796 and Extending the radiocarbon calibration beyond 26,000 years before present using fossil corals by Chiu, T.C., 2005. Quaternary Science Reviews 24, 1797-1808. Quaternary Science Reviews 25, 855-862.

Rieley J.O., Ahmad-Shah A.A., Brady M.A., 1996. The extent and nature of tropical peat swamps - Tropical Lowland Peatlands of Southeast Asia. In: Maltby E., Immirzi C.P., Safford R.J. (Eds.), Tropical Lowland Peatlands of Southeast Asia -proceedings of a workshop on integrated planning and management of tropical lowland peatlands: workshop on integrated planning and management of tropical lowland peatlands. IUCN, Gland, Switzerland.

Routh, J., Meyers, P.A., Gustafsson, O., Baskaran, M., Hallberg, R., Scholdström, A., 2004. Sedimentary geochemical record of human-induced environmental changes in the Lake Brunnsviken watershed, Sweden. Limnology and Oceanography 49 (5), 1560-1569.

Sage, R.F., Wedin, D.A., Li, M., 1999. The Biogeography of C4 Photosynthesis: Patterns and Controlling Factors in: Sage, R.F., Monson, R.K. (Eds.), C4 Plant Biology. Academic Press, San Diego, pp. 313-373. 
894

895

896

897

898

899

900

901

902

903

904

905

906

907

908

909

910

911

Schefusz, E., Kuhlmann, H., Mollenhauer, G., Prange, M. \& Patzold, J., 2011. Forcing of wet phases in southeast Africa over the past 17,000 years. Nature Geoscience 480 (7378), $509-512$

Schmittner, A., Saenko, O.A., Weaver, A.J., 2003. Coupling of the hemispheres in observations and simulations of glacial climate change. Quaternary Science Reviews 22 (5-7), 659-671.

Skrzypek, G., Jezierski, P., Szynkiewicz, A., 2010. Preservation of primary stable isotope signatures of peat-forming plants during early decomposition - observation along an altitudinal transect. Chemical Geology 273 (3-4), 238-249.

Skrzypek, G., Paul, D., Wojtun, B., 2008. Stable isotope composition of plants and peat from Arctic mire and geothermal area in Iceland. Polish Polar Research 29 (4), 365-376.

Smuts, W.J., 1992. Peatlands of the Natal mire complex: geomorphology and characterization. South African Journal of Science 88 (9-10), 474-483.

Staub, J.R., Esterle, J.S., 1994. Peat-accumulating depositional systems of Sarawak, East Malaysia. Sedimentary Geology 89 (1-2), 91-106.

Stenni, B., Masson-Delmotte, V., Johnsen, S., Jouzel, J., Longinelli, A., Monnin, E., Röthlisberger, R., Selmo, E., 2001. An oceanic cord reversal during the last deglaciation. Science 293 (5537), 2074-2077. 
Stock, W.D., Chuba, D.K., Verboom, G.A., 2004. Distribution of South African C3 and C4 species of Cyperaceae in relation to climate and phylogeny. Austral Ecology 29 (3), 313319.

Stocker, T.F., 2000. Past and future reorganizations in the climate system. Quaternary Science Reviews 19 (1-5), 301-319.

Stokes, S., Thomas, D.S.G., Washington, R., 1997. Multiple episodes of aridity in southern Africa since the last interglacial period. Nature 388 (6638), 154-158.

Strack, M., 2008. Peatlands and climate change. International Peat Society, Jyvaskyla, Finland.

Stuiver, M., Polach, H.A., 1977. Discussion: Reporting on ${ }^{14} \mathrm{C}$ data. Radiocarbon 19 (3), 355363.

Talma, A., Vogel, J.C., 1992. Late Quaternary paleotemperatures derived from a speleothem from Cango caves, Cape Province, South Africa. Quaternary Research 37 (2), 203-213.

Taylor, R., Kelbe, B., Haldorsen, S., Botha, G.A., Wejden, B., Varet, L., Simonsen, M.B., 2006a. Groundwater-dependent ecology of the shoreline of the subtropical Lake St Lucia estuary. Environmental Geology 49 (4), 586-560.

Taylor, R., Adams, J.B., Haldorsen, S., 2006b. Primary habitats of the St Lucia estuarine system, South Africa, and their responses to mouth management. African Journal of Aquatic Science 31 (1), 31-41. 
Turunen, J., Tomppo, E., Tolonen, K., Reinikainen, A., 2002. Estimating carbon accumulation rates of undrained mires in Finland - Application to boreal and subarctic regions. Holocene 12 (1), 69-80.

Tyson, P.D., Preston-Whyte, R.A., 2000. The weather and climate of southern Africa, Oxford University Press Incorporated, Cape Town, South Africa.

Vaeret, L., Sokolic, F., 2008. Methods for studying the distribution of groundwaterdependent wetlands: a case study from Eastern Shores, St Lucia, South Africa, in: Responses to global change and management actions in coastal groundwater resources, Norwegian University of Life Sciences.

Valsecchi, V., Chase, B.M., Slingsby, J.A., Carr, A.S., Quick, L.J., Meadows, M.E., Cheddadi, R. \& Reimer, P.J., 2013. A high resolution 15,600-year pollen and microcharcoal record from the Cederberg Mountains, South Africa. Palaeogeography, Palaeoclimatology, Palaeoecology 387, 6-16.

Venter, C.E., 2003. The vegetation ecology of Mfabeni peat swamp, St Lucia, KwaZulu-Natal. MSc Thesis, University of Pretoria.

Vogel, J.C., Fuls, A., 1978. The Geographical Distribution of Kranz Grasses in South Africa. South African Journal of Science 74, 209-215.

Vrdoljak, S.M., Hart, R.C., 2007. Groundwater seeps as potentially important refugia for freshwater fishes on the Eastern Shores of Lake St Lucia, KwaZulu-Natal, South Africa. African Journal of Aquatic Science 32 (2), 125-132. 
951 Walther, S.C., Neumann, F.H., 2011. Sedimentology, isotopes and palynology of late

952 Holocene cores from Lake Sibaya and the Kosi Bay system (KwaZulu-Natal, South

953 Africa). South African Geographical Journal 93 (2), 133-153.

954 Worrall, F., Reed, M., Warburton, J., Burt, T., 2003. Carbon budget for a British upland peat

955 catchment. Science of the Total Environment 312 (1-3), 133-146.

956 


\section{Tables}

958 Table 1: Sediment properties with averaged accumulation data for the five LSR stages in

959 core SL6

\begin{tabular}{|c|c|c|c|c|c|c|c|c|}
\hline Core \# & $n$ & $\begin{array}{c}\text { Sediment } \\
\text { type }\end{array}$ & Porosity & $\begin{array}{c}\text { Bulk Density } \\
\text { g.cm-3 }\end{array}$ & $\begin{array}{c}\text { LSR }^{\mathrm{a}} \\
\text { mm.yr } \\
\end{array}$ & $\begin{array}{c}\text { MAR }^{b} \\
\text { g.m }{ }^{-2} \cdot \mathrm{yr}^{-1} \\
\end{array}$ & $\begin{array}{c}\text { TOC } \\
\text { gC. } \mathrm{m}^{-2} \\
\end{array}$ & $\begin{array}{c}\text { C Accumulation } \\
\text { g C.m-2. } \mathrm{yr}^{-1}\end{array}$ \\
\hline \multicolumn{9}{|c|}{ Averages } \\
\hline LSR 1 & 38 & Peat & 0.73 & 0.29 & 0.13 & 37.6 & 1068 & 13.6 \\
\hline LSR 2 & 20 & Peaty sand & 0.64 & 0.34 & 0.22 & 76.4 & 553 & 12.4 \\
\hline LSR 3 & 22 & Peat & 0.73 & 0.28 & 0.15 & 41.4 & 896 & 13.0 \\
\hline LSR 4 & 20 & peat & 0.72 & 0.28 & 0.10 & 28.1 & 711 & 7.4 \\
\hline LSR 5 & 98 & peat & 0.69 & 0.24 & 0.29 & 70.9 & 1108 & 32.3 \\
\hline
\end{tabular}

960

${ }^{a}$ LSR $=$ Linear Sedimentation Rate

${ }^{b}$ MAR = Mass Accumulation Rate

961

962

963 
964 Table 2: Chronology of Mfabeni peatland core SL6 with uncalibrated AMS ${ }^{14} \mathrm{C}$ dates,

965 corresponding percentage total organic carbon (TOC) and bulk stable carbon isotope values

966

\begin{tabular}{cccccc}
\hline $\begin{array}{c}\text { Sample } \\
\text { code }\end{array}$ & $\begin{array}{c}\text { Depth } \\
(\mathbf{c m})\end{array}$ & Material & $\begin{array}{c}\text { uncalibrated } \\
\text { date }\end{array}$ & $\% \mathbf{C}$ & $\mathbf{\delta}^{\mathbf{1 3}} \mathbf{C}_{\text {TOC }}$ \\
\hline SL6 10-11 & 10 & Peat & $109 \pm 0.35 \mathrm{pMC}$ & 45.1 & -21.8 \\
SL6 109-110 & 109 & Peat & $3240 \pm 30 \mathrm{BP}$ & 51.9 & -16.8 \\
SL6 209-210 & 209 & Peat & $6170 \pm 30 \mathrm{BP}$ & 19.2 & -24.5 \\
SL6 309-310 & 309 & Peat & $9270 \pm 70 \mathrm{BP}$ & 37.1 & -21.5 \\
SL6 405-406 & 405 & Peat & $16940 \pm 80 \mathrm{BP}$ & 14.7 & -19.1 \\
SL6 510-511 & 510 & Peat & $22800 \pm 130 \mathrm{BP}$ & 29.6 & -18.6 \\
SL6 609-610 & 609 & Peat & $27600 \pm 190 \mathrm{BP}$ & 22.5 & -19.0 \\
SL6 709-710 & 709 & Peat & $>48000 \mathrm{BP}$ & 28.1 & -17.6 \\
SL6 805-806 & 805 & Peat & $49000 \pm 2200 \mathrm{BP}$ & 12.2 & -20.1 \\
\hline
\end{tabular}


968 Table 3: Statistical relationships between isotopic and elemental profiles for LSR stages in

969 Core SL6. (Two tail test, $P=$ probability level, $d f=$ degrees of freedom)

\begin{tabular}{ccccc}
\hline & $\delta^{15} \mathrm{~N}: \mathrm{C} / \mathrm{N}$ & $\delta^{13} \mathrm{C}: \mathrm{C} / \mathrm{N}$ & $\delta^{15} \mathrm{~N}: \delta^{13} \mathrm{C}$ & $\% \mathrm{~N}: \% \mathrm{C}$ \\
\hline LSR Stage 1 & & & & \\
$\quad \mathrm{r}$ & 0.34 & 0.61 & 0.39 & 0.90 \\
$(\mathrm{P}=\mathbf{0 . 0 1 ;} \mathrm{df}=36)$ & & $\mathrm{Sig}$ & & $\mathrm{Sig}$
\end{tabular}

$\begin{array}{ccccc}\text { LSR Stage } 2 \\ \mathbf{r} & -0.78 & -0.66 & 0.52 & 0.99 \\ (\mathbf{P}=\mathbf{0 . 0 1} ; \mathbf{d f}=\mathbf{1 5}) & \mathbf{S i g} & \mathbf{S i g} & & \text { Sig }\end{array}$

$\begin{array}{lcccc}\text { LSR Stage } 3 & & & \\ \mathbf{r} & -0.69 & 0.83 & -0.36 & 0.84 \\ (\mathbf{P}=\mathbf{0 . 0 1} ; \mathbf{d f}=\mathbf{2 0}) & \mathbf{S i g} & \mathbf{S i g} & & \mathbf{S i g}\end{array}$

$\begin{array}{lllll}\begin{array}{c}\text { LSR Stage } 4 \\ \mathbf{r}\end{array} & 0.25 & 0.84 & -0.36 & 0.98 \\ (\mathbf{P}=\mathbf{0 . 0 1 ;} \mathbf{d f}=\mathbf{1 8}) & & \mathbf{S i g} & & \mathbf{S i g}\end{array}$

\begin{tabular}{|c|c|c|c|c|}
\hline LSR Stage 5 & & & & \\
\hline $\begin{array}{c}r \\
(P=0.01 ; d f=97)\end{array}$ & 0.06 & 0.16 & -0.18 & $\begin{array}{c}0.46 \\
\text { Sig }\end{array}$ \\
\hline
\end{tabular}

970

971 


\section{Figure Captions}

974 Figure 1: Mfabeni Peatland, iSimangaliso Wetland Park, St Lucia, northern KwaZulu Natal, 975 South Africa with major habitat groups and dominant water bodies represented.

$976 \quad$ Figure 2: Core SL6 stratigraphic profile with modelled ages.

977 Figure 3: Core SL6 age-depth model with uncertainty ranges. AMS ${ }^{14} \mathrm{C}$ dates were calibrated 978 with IntCal09 curve (Reimer et al., 2006) with a southern Hemisphere offset of c. $40 \pm 20{ }^{14} \mathrm{C}$ 979 years. Postbomb dates calibrated with southern Hemisphere postbomb curve by Hua and 980 Barbetti (2004). All dates were adjusted within the Bayesian framework, using Bacon age 981 depth modelling software (Blaauw and Christen 2011).

Figure 4: Downcore profile of Core SL6 presenting linear sedimentation rate (LSR), mass accumulation rate (MAR), total organic carbon (TOC) and carbon accumulation rate (CAR) with age and depth. Red line represents total core average. Hol $=$ Holocene, $Y D=$ Younger Dryas; H1-5 = Heinrich events, LGM = Last Glacial Maximum. Heinrich dates after Hemming 986 (2004).

Figure 5: SL6 down core profile representing stable $\mathrm{C}$ and $\mathrm{N}$ isotope signals, elemental weight percentages for $\mathrm{C}$ and $\mathrm{N}$ and atomic $\mathrm{C} / \mathrm{N}$ ratio. $\mathrm{Hol}=$ Holocene, $\mathrm{H} 1-5=$ Heinrich events, LGM = Last Glacial Maximum. Heinrich dates after Hemming (2004).

990 Figure 6: Proportion of carbon input from C4 plants (Equation 1, see methods section 2.5). Hol = Holocene, $\mathrm{H1}-5=$ Heinrich events, LGM = Last Glacial Maximum. Heinrich dates after Hemming (2004). 
Figure 1

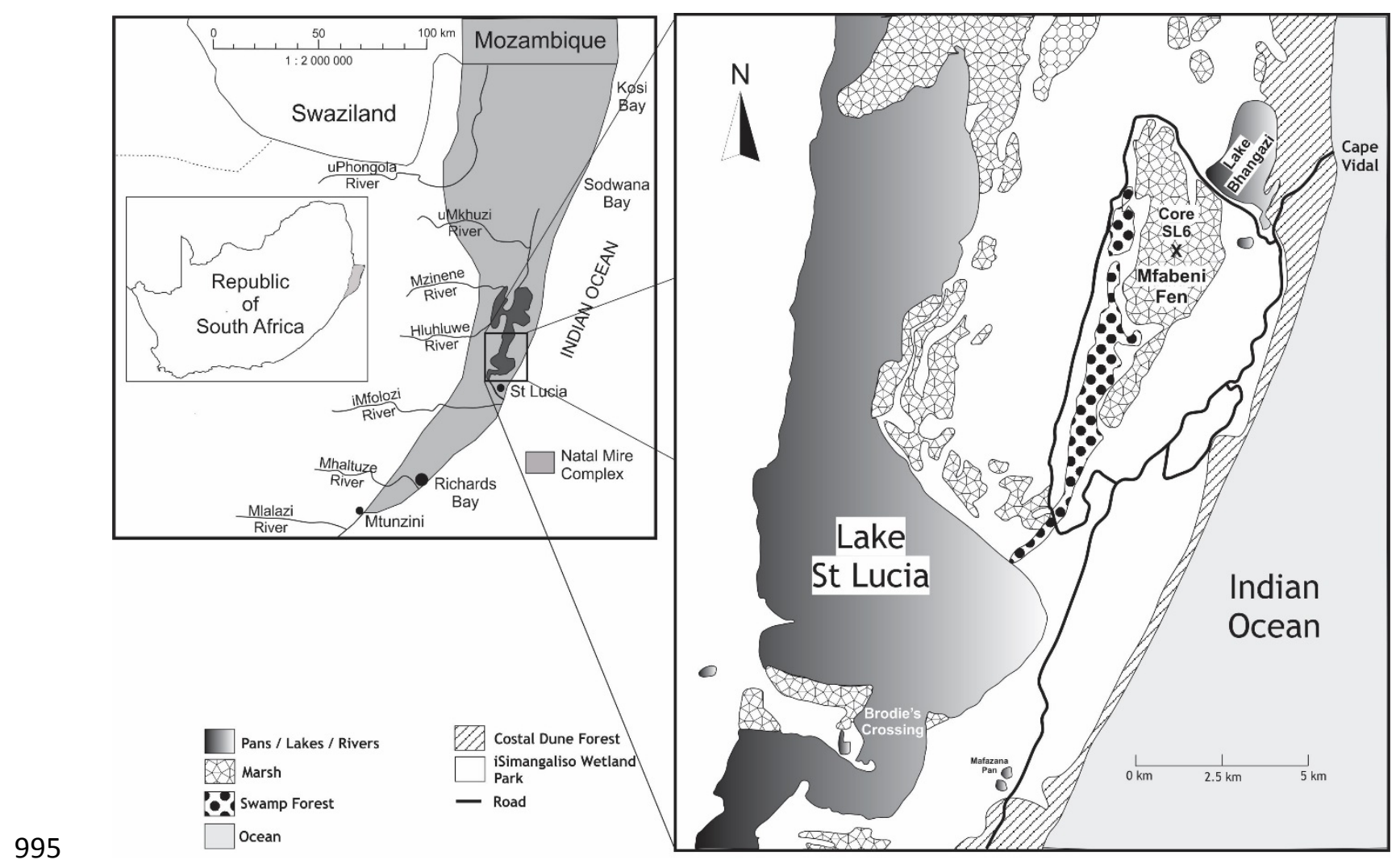

996

997 


\section{Core SL6}

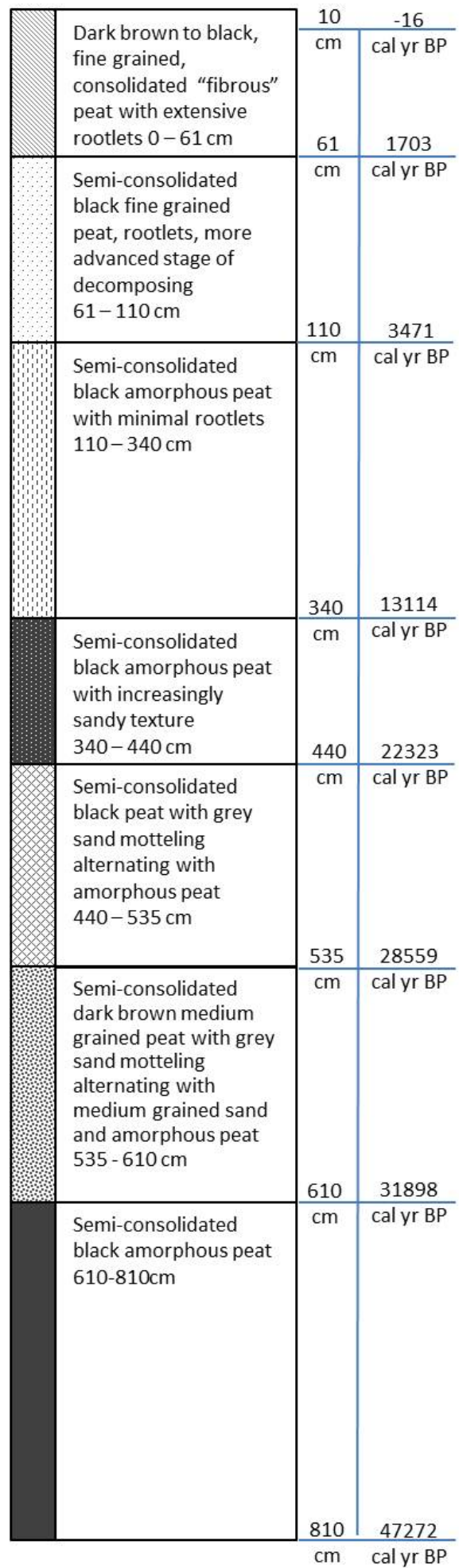

\section{Not to Scale}


$1000 \quad$ Figure 3

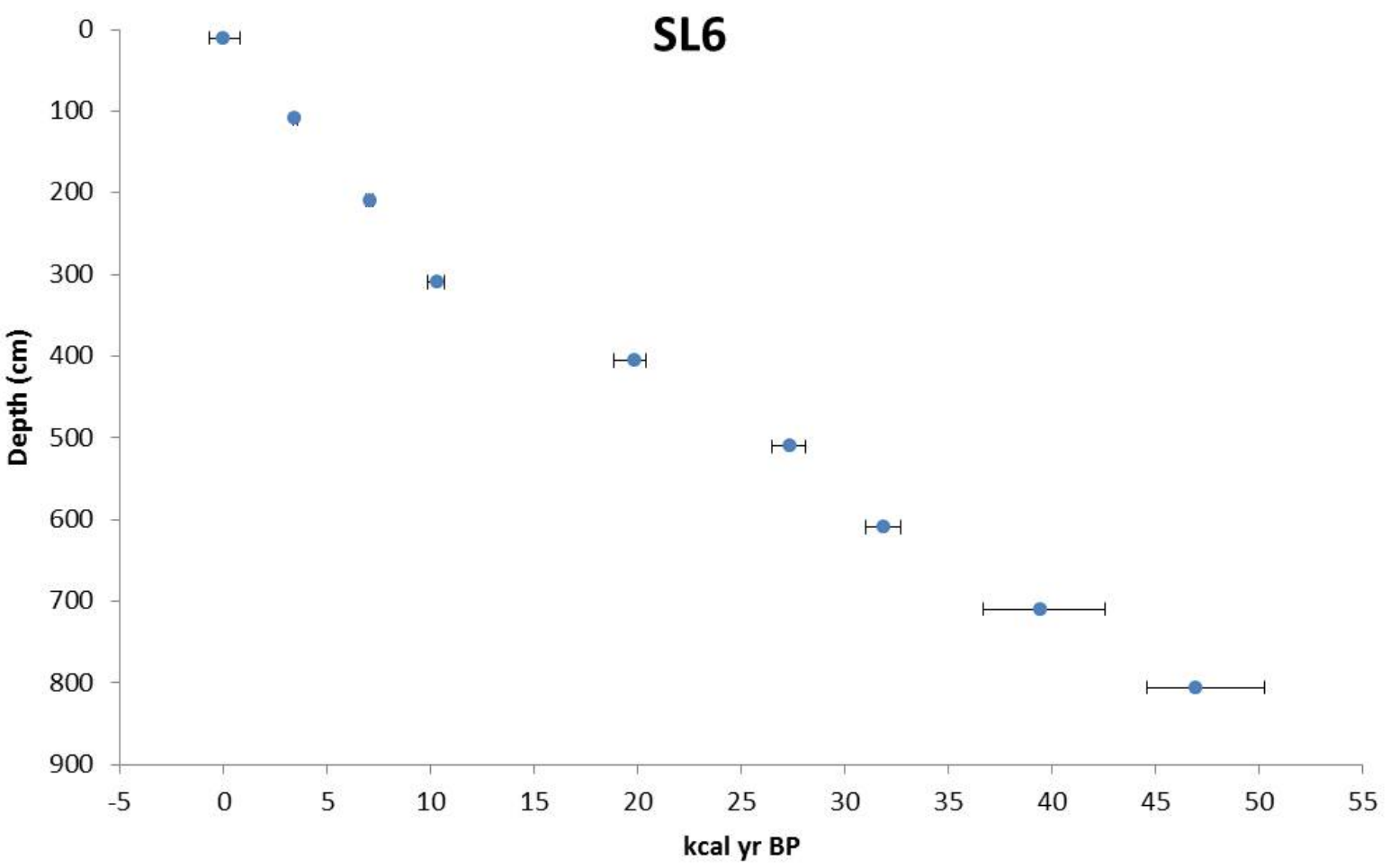

1001

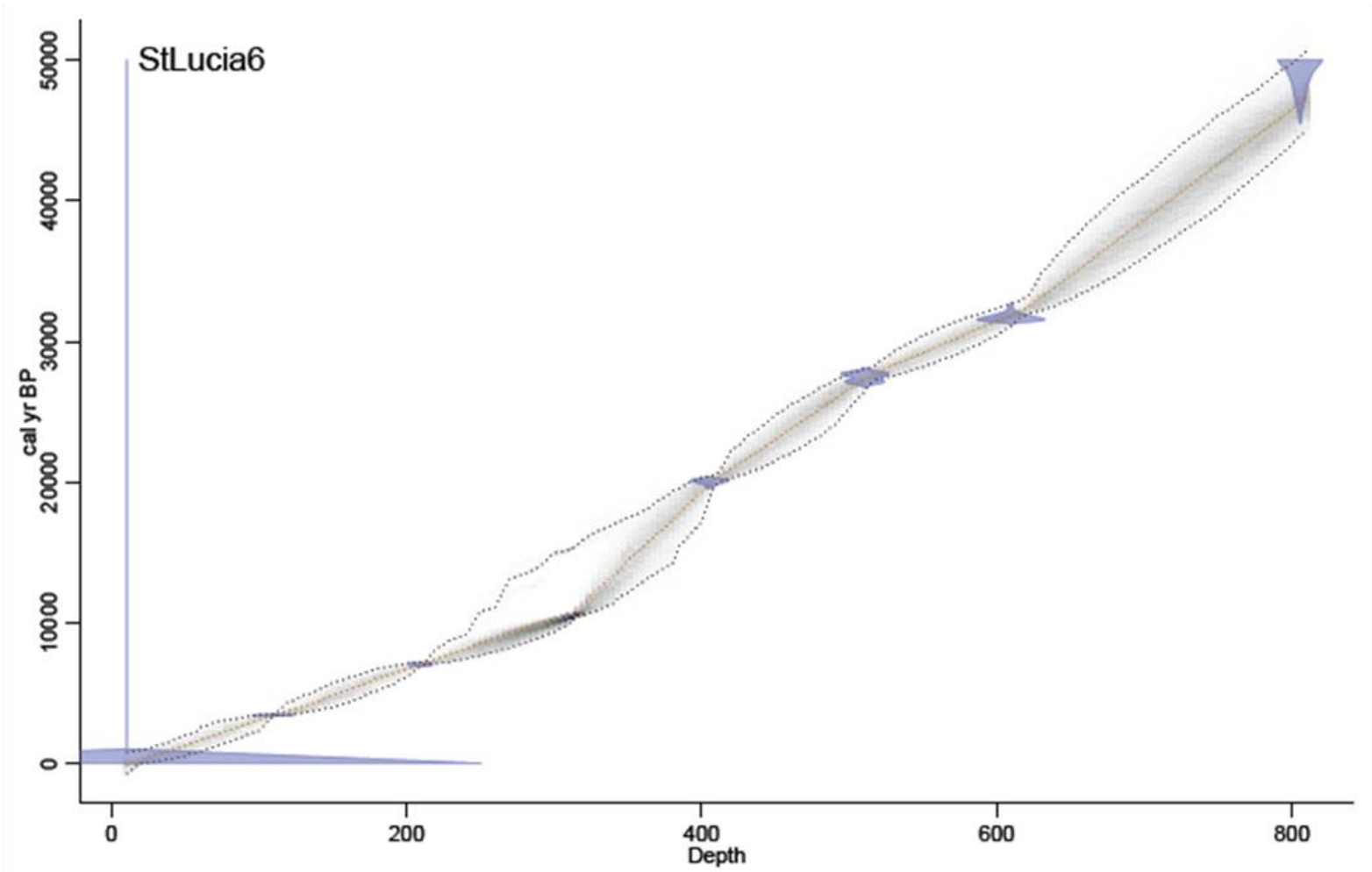

1002

1003 


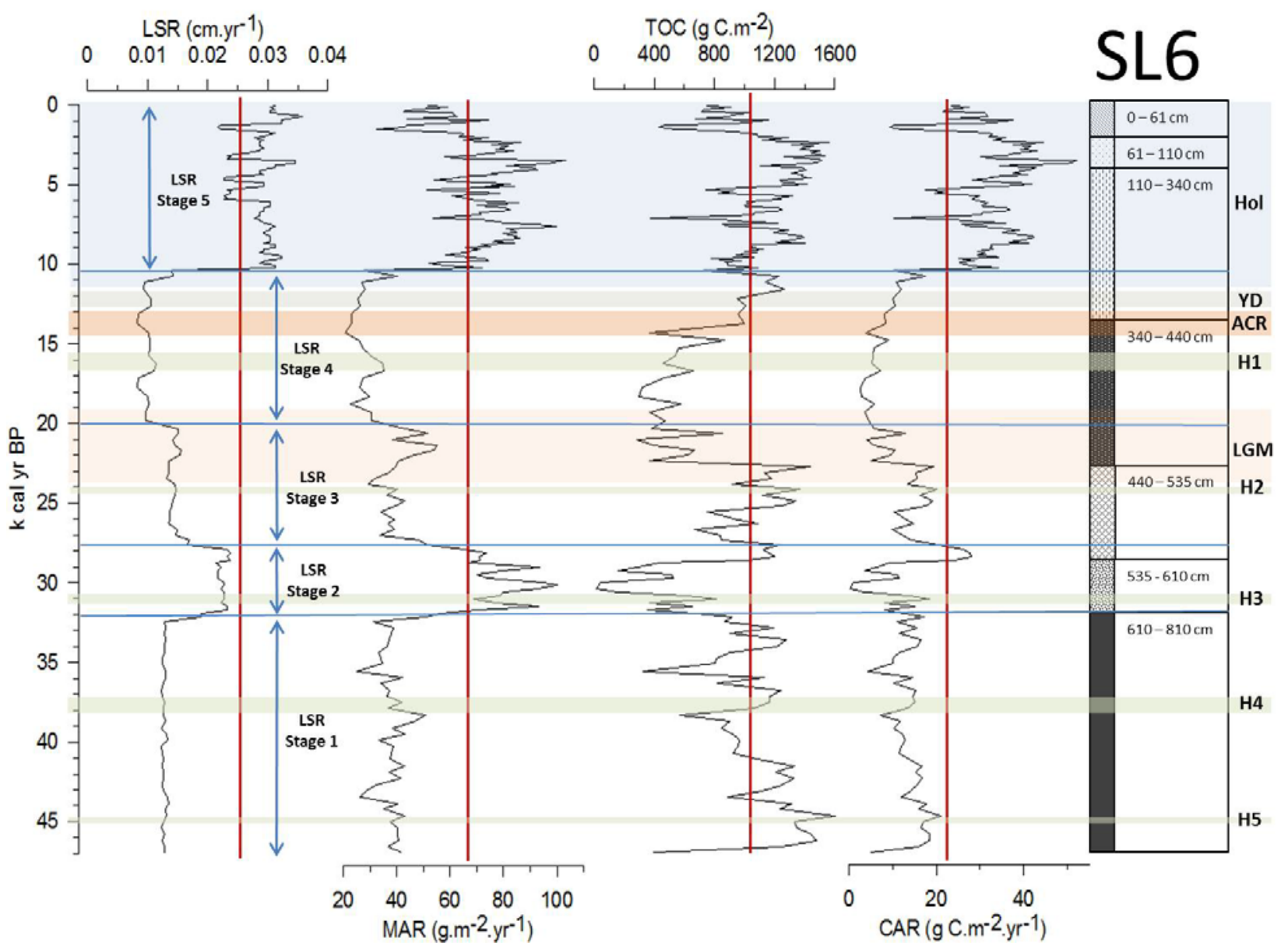




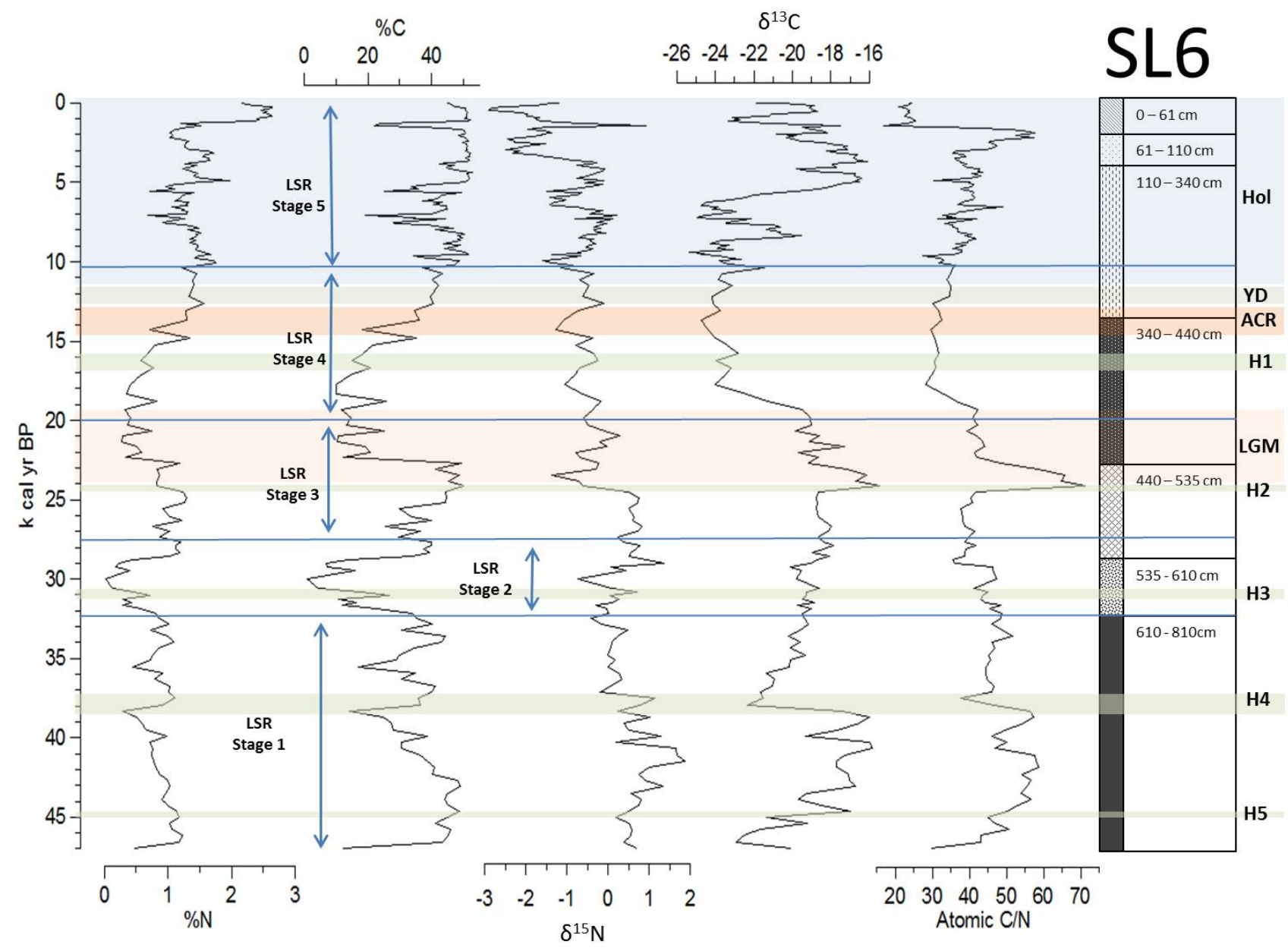


$1010 \quad$ Figure 6

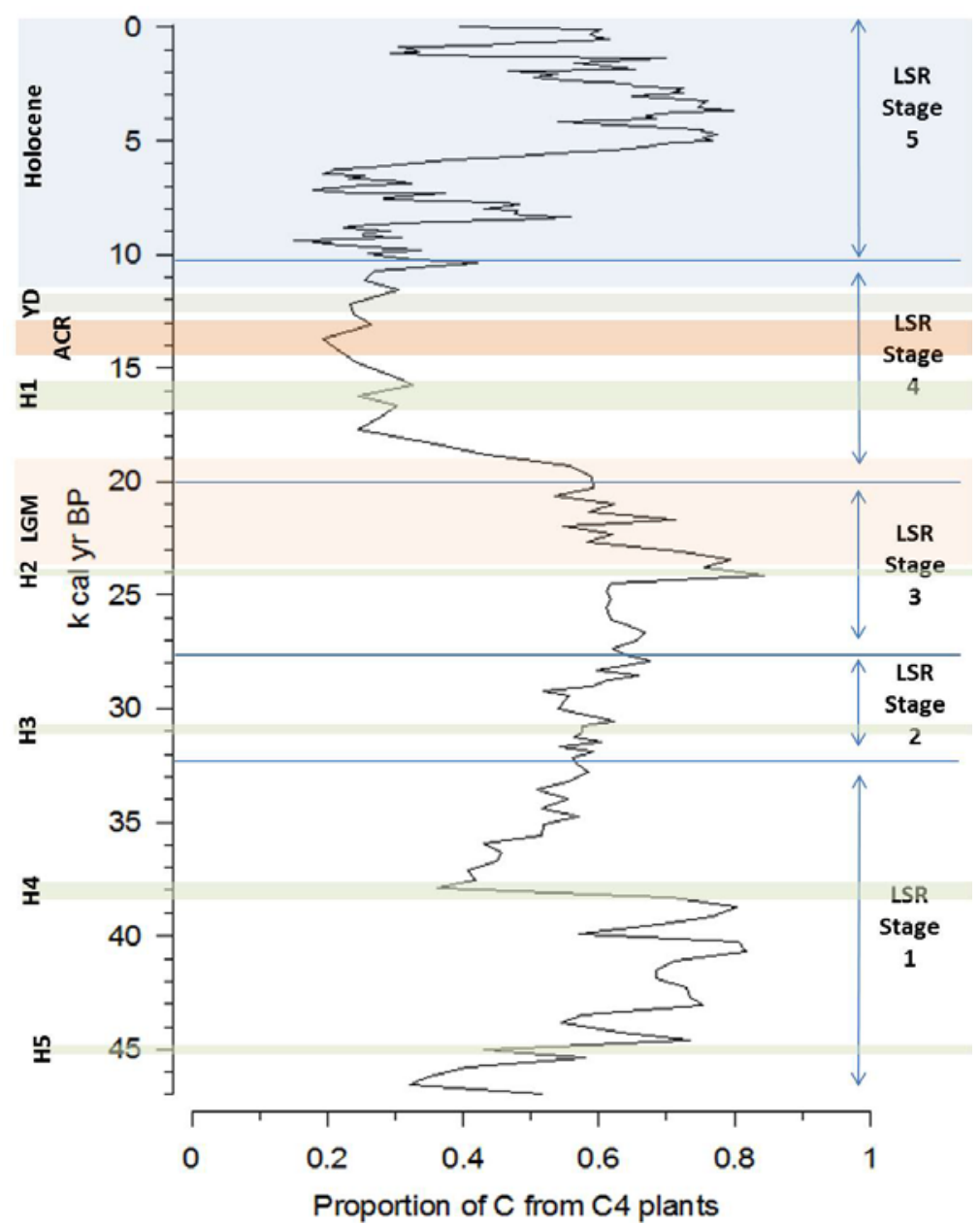

1011 